Historic, archived document

Do not assume content reflects current scientific knowledge, policies, or practices. 


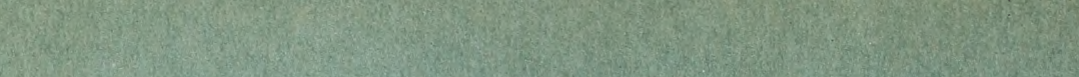

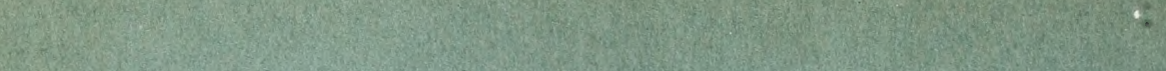

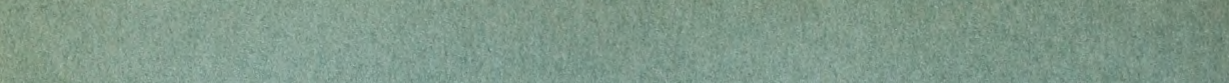

-5. 


\section{BIOLOGY OF THE TOBACCO MOTH AND ITS CONTROL IN CLOSED STORAGE}

By W. D. REeD, associate entomologist, and E. M. Livingstone, junior entomologist, Division of Truck Crop and Garden Insect Investigations, Bureau of Entomology and Plant Quarantine ${ }^{1}$

\section{CONTENTS}

\begin{tabular}{|c|c|c|c|}
\hline Introduction & $\begin{array}{r}\text { Page } \\
1\end{array}$ & Life-history studies of 1932 and 1933-Contd. & Page \\
\hline Iistory and distribution of the tobaceo moth & 1 & Oviposition and longevity & 14 \\
\hline ijury to tobacco & 3 & Temperature. & \\
\hline Economic importance of tobacco moth & & Incubation period. & \\
\hline infestation & 4 & Larval period... & \\
\hline General discussion of the insect. & 5 & Pupal period. & \\
\hline The & 5 & Length of life cycle. & \\
\hline The egg & 8 & Control & \\
\hline Th & 8 & Natu & \\
\hline The & 10 & Temperat & \\
\hline easo & 11 & Artificial control in closed storage & \\
\hline Life-history studies of 1932 and 1933 & [2 & Summary. & \\
\hline Methods and apparatus . - & 12 & Literature cited .. & \\
\hline Spring eme & & & \\
\hline
\end{tabular}

\section{INTRODUCTION}

During the years 1931 to 1934 the writers devoted considerable time to the study and observation of the life history, habits, and control of the tobacco moth (Ephestia elutella $\mathrm{Hbn}$.). This is a comparatively new pest of cured tobacco in the United States, and, owing to the great interest aroused by its discovery as a tobacco pest, two preliminary papers have already been published. In 1930 Back and Reed (2) 2 reported the discovery of this moth attacking flue-cured tobacco, and in 1933 Reed et al. (18) published a progress report of studies on the insect. Beginning in 1931, matings were made from the progeny of each generation of moths reared in the laboratory and rearings obtained for the succeeding generation. These life-history studies and the more important observations covering a period of 2 years are summarized in this circular.

\section{HISTORY AND DISTRIBUTION OF THE TOBACCO MOTH}

The moth Ephestia elutella has been known for years by entomologists as a general feeder on dried vegetable products. Owing to its diversity of food habits it has been transported by commerce to vari-

1 The writers are grateful for the advice of E. A. Back, under whose direction this work was carried out, and to A. W. Morrill, Jr., K. H. Smith, and C. W. Kearns for assistance in carrying out the control experiments.

2 Italic numbers in parentheses refer to Literature Cited, p. 37.

$$
101216^{\circ}-37-1
$$


ous parts of the world. As early as 1737 Reaumur (16, pp. 275-2yy) recorded a moth attacking chocolate, and it is likely that he was referring to $E$. elutella. In 1897 Chittenden $(5, p .9)$ stated that the food habits of the moth had been known in Europe since early in the eighteenth century.

A review of entomological literature made by the present writers and others shows that Ephestia elutella is world-wide in distribution. The most complete bibliography on the genus Ephestia was that published by Richards and Thomson (20, pp. 2.31-246) in 1932. It is worth while, however, to record here that, outside of references to infestation of tobacco and cacao, nothing positive is given regarding the extent of injury by the insect. This leads to the assumption that there are factors in the biology of the pest that retard multiplication or reduce the population in stored products. It is sometimes found in infestations associated with the Indian-meal moth (Plodia interpunctella $\mathrm{Hbn}$.), the fig moth (Ephestia cautella Walk.), the raisin moth (E. figulilella Greg.), and the Mediterranean flour moth (E. kuehniella Zell.), but it apparently fails to build up as large populations as the other species mentioned. Maskew (9), in 1912, published an account of an infestation by $E$. elutella in a shipment of walnuts received at San Francisco, Calif., from Manchuria, and stated that the infestation was serious. De Ong (6) reported that peanuts received at San Francisco from China in the fall of 1924 were heavily infested by $E$. elutella. He referred to the insect by the common name of currant moth. Gibson and Twinn $(\%, p .29)$ merely reported the presence of the insect in Canada and gave no information concerning the extent of the injury. The foregoing references represent the published accounts of the occurrence of the moth in North America prior to 1930. It is reasonable to assume that if the moth had been a serious pest of a variety of stored products, more information concerning its ravages would be found in the literature.

Because in recent years the tobacco moth has developed into a major pest of cigarette-type tobaccos, it is considered important to mention any literature references concerning infestation of tobacco. Mokrzecki and Bragina (11) in 1913-14 discovered larvae of Ephestia elutella infesting cured tobacco in the Crimea. Tchorbadjief, in 1928 (21), reported the moth as a pest of stored tobacco in Bulgaria. On September 9, 1930, there appeared an article $^{3}$ which stated that larvae of E. elutella had appeared in stocks of Rhodesian tobacco held in bond in a London warehouse. It was feared that this infestation would cause the tobaccos to depreciate in value. Back and Reed (2), in December 1930, reported the discovery of this moth infesting flue-cured, cigarette-type tobaccos in a few warehouses in Richmond, Va. As stated previously, this was the first published record of its appearance as a pest of tobacco in the United States. Mokrzecki (10), who in 1930 published his observations from 1909 to 1930 on the biology and control of E. elutella in the tobacco-storage warehouses of Poland, reported that the pest had been observed infesting cured tobacco in Simferopol and Yalta, Crimea; Sukhum, Caucasus; Philippopol, Bulgaria; and Poland. He observed also that larvae of the moth were imported into Poland in tobacco purchased

${ }^{3}$ HILl, B. D. THE TOBACCO SITUATION IN SOUTH AFRICA AND SOUTHERN RHODESIA. U. S. Dept. Com., Bur. Foreign and Dom. Com. Circ. 270: 5-7. 1930. [Mimeographed.] 
in Greece and Bulgaria. In 1931 Bovingdon (3) recorded the appearance of $E$. elutella in stores of tobacco in England, Bulgaria, the Union of Soviet Socialist Republics, and the United States.

In 1932 Jack $(8, p .33)$ stated that Ephestia elutella was found in Salisbury, Southern Rhodesia, infesting tobacco and chocolate but that there was no record of its occurrence in Northern Rhodesia or Nyasaland.

Mossop (12, pp. 3-4) recorded the moth in Salisbury infesting imported chocolate in April 1930 and infesting stored tobacco in June of the same year. He stated also that it had been recorded as a pest of peanuts in Nyasaland in 1915, and that the discovery of this moth in London and Salisbury led to the passage in 1931 of the Tobacco Pest Suppression Act, which-

provides for the licensing of all premises where unmanufactured tobacco is prepared or held for export, for the inspection and cleansing of all such warehouses, and for the destruction of infested tobacco where necessary.

Reed et al. (18) published a paper in 1933 giving the results of preliminary studies on the biology of the moth and recording observations made in tobacco warehouses in Virginia in 1930 and 1931. Ustinov (22), in 1932, mentioned that this moth was found throughout the southern part of the Union of Soviet Socialist Republics infesting tobacco.

Bovingdon (4), in May 1933, published a comprehensive report on the infestation of cured tobacco in London warehouses by the tobacco moth, including notes on the biology and control of the pest.

Reed (17), in February 1935, published a report of a survey made in the Near East in 1933, which showed that the tobacco moth was widely distributed in the tobacco districts of Greece and Turkey. Data given in this report showed that the moth was more generally distributed throughout these countries than the cigarette beetle.

Infestations of the moth were observed from 1931 to 1934 in warehouses of cigarette tobaccos of the flue-cured and Turkish types in Virginia, North Carolina, New York, and New Jersey, but no infestations were found in Burley, dark-fired, or cigar types of tobacco, and efforts to rear the moth on these types in the laboratory were unsuccessful.

\section{INJURY TO TOBACCO}

The larvae of the tobacco moth are responsible for the damage to cured tobacco. They begin feeding in some instances within a few hours after the eggs have hatched, eating first the cuticle of the leaf. After the first molt they begin eating the entire leaf, avoiding only the larger veins (fig. 1). Feeding often begins at the stem end of leaves and proceeds toward the tip. In general, the details of feeding: are quite similar to those of many species of leaf-eating caterpillars. Much of the tobacco not consumed by the larvae during their development is soiled and rendered worthless by the webbing and excrement of nearly mature individuals that spin threads of silk as they move about in the tobacco leaves, their fresh pellets of excrement adhering to this silk. In some instances as much tobacco is rendered worthless by the webbing and excrement as is consumed by the insects. In infested hogsheads or bales of tobacco this webbing presents an unsightly appearance. The injury by the larvae does not often extend 
deeper than 3 inches from the staves of hogsheads, although in one tobacco warehouse the larvae were found feeding to a depth of 8 inches.

\section{ECONOMIC IMPORTANCE OF TOBACCO MOTH INFESTATION}

The tobacco moth has been found infesting only the various grades of flue-cured domestic and imported Turkish tobaccos used in the

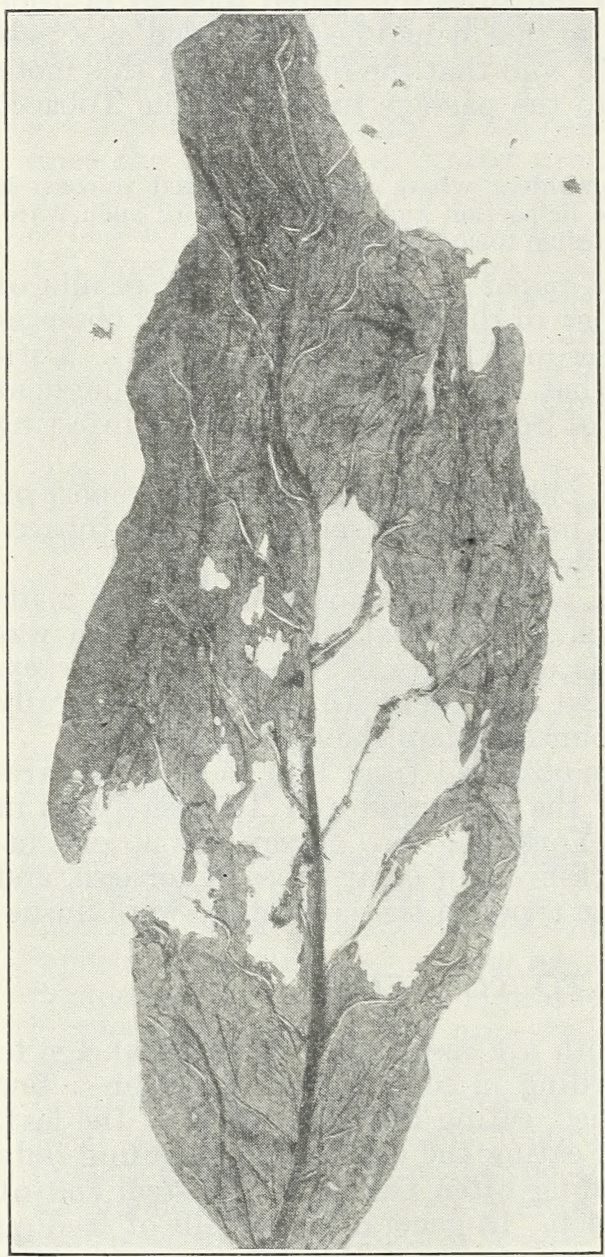

Figure 1.-Leaf of flue-cured cigarette-type tobacco showing result of feeding by larvae of the tobacco moth. manufacture of cigarettes. Tobacco leaves of the fluecured types, when properly aged for manufacture, are reported to contain from 5 to 27 percent of sugar and the Turkish types from 3 to 17 percent. This is a reducing sugar, principally levulose. The larvae of the tobacco moth thrive on those grades of tobacco high in sugar content. In tobacco warehouses it was observed that grades of tobaccos low in sugar may be uninfested, whereas grades high in this substance stored nearby were severely injured. The higher priced commercial grades of cigarette tobaccos usually run highest in sugar. The fact that the moth attacks more severely these high-priced grades of tobacco makes an infestation by the insect of great economic importance.

A typical hogshead of flue-cured to b a c co is 54 inches high and 48 inches in diameter and contains approximately 1,000 pounds of tobacco (fig. 2). One such hogshead c on t a in ed 983 pounds of tobaceo and the volume was 82,648 cubic inches. The weight of each cubic inch of tobacco in this hogshead was 0.0119 pound and the weight of tobacco for each inch of depth in from the staves, uip to 3 inches, was as follows: 
The infested tobacco leaf may be rendered worthless by the larvae, although in some instances a part of the leaf can be salvaged. Studies showed that by a conservative estimate 20 percent by weight of each pound of heavily infested tobacco was lost, this loss being chargeable directly to the moth. Flue-cured tobacco, aged and redried, will average in value at present prices (November 1936) around 30 cents per pound. The loss per infested hogshead for each inch of infestation based on the foregoing figures would be as follows :

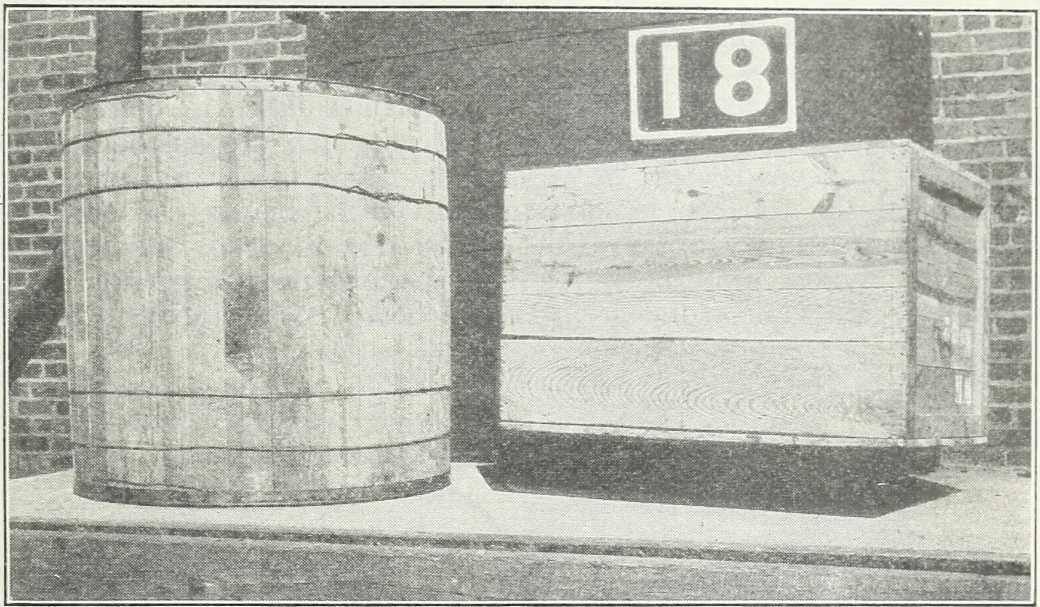

Figure 2.-Hogshead of flue-cured cigarette-type tobacco $4 \frac{1}{2}$ feet high and 4 feet in diameter at left. The weight of the tobacco in this hogshead was approximately 1,000 pounds. The case of cigarette-type tobacco at right, 30 by 30 by 48 inches, contained about 500 pounds of flue-cured tobacco.

1 inch $\$ 7.08$

2 inches 13.55

3 inches -19. 45

There are more than 650,000 hogsheads (650 million pounds) of flue-cured tobacco in storage in the United States at all seasons of the year. This enormous stock in storage emphasizes the importance of exercising precautions to control infestations of the tobacco moth, for if 300,000 hogsheads should become infested during the season to a depth of 1 inch, which is well within the realm of possibility, the loss to the industry would be approximately $\$ 2,124,000$ annually.

The tobacco case shown in figure 2 measures 30 by 30 by 48 inches and contains about 500 pounds of tobacco. Only a small percentage of the total quantity of cigarette tobacco is packed in cases.

\section{GENERAL DISCUSSION OF THE INSECT}

\section{THE ADULT}

The coloration of tobacco moths is variable; some are gray, others light grayish brown. The forewings and body of newly emerged specimens often have a brownish tinge. Two light-colored bands extend across each forewing. The adults kept in captivity often lose many of the wing scales and soon appear light gray in color. 
With the wings folded they measure about three-eighths of an inch from head to tip of wings and when the wings are outspread the width is approximately five-eighths of an inch from wing tip to wing tip. When at rest the moths hold the delicate threadlike antennae back over the head and body.

\section{EMERGENCE}

The moth (fig. 3) emerges from the pupal case by forcing it open at the anterior end. In some instances the pupal case is enclosed in a loosely woven silken cocoon, whereas in others it is virtually naked. The larvae habitually migrate when full-grown and pupate in sheltered locations from which it will be convenient for the adults to emerge. The places selected are sometimes holes in brick walls, spaces beneath wooden runners which support hogsheads, or the surfaces of hogsheads near large cracks. This migration of grown larvae from the tobacco is particularly noticeable in the fall. In one warehouse under observation all of the tobacco was removed during the winter months, but a large emergence of spring moths occurred in May and June from larvae that overwintered in hiding places.

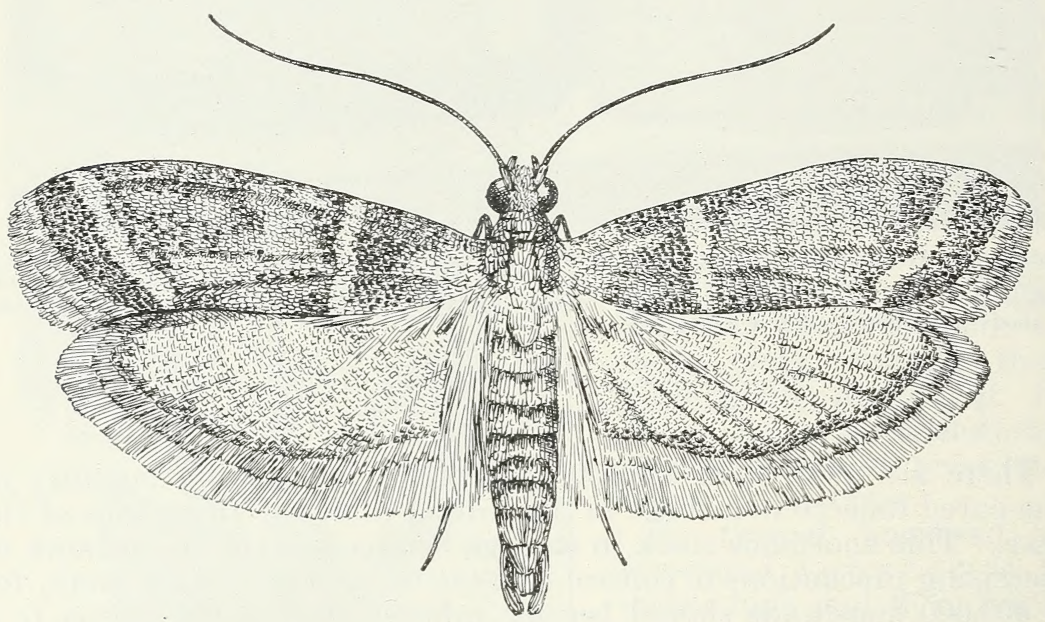

Figure 3.-The tobacco moth, Ephestia elutella. $\times 7$.

The newly emerged moth begins immediately to unfold its wings, holding them upright over the back until dry. This process requires about 15 or 20 minutes.

MATING

The moths generally mate late in the afternoon or early in the evening, the time of day corresponding to the period of their greatest activity. Mating may be observed, however, at other times of the day. Unfertilized females characteristically sit with the wings folded, and with the tip of the abdomen pointing slightly upward. The males locate females apparently by odor, and the courtship consists in the male pirouetting around for a few seconds in front of the female. In the warehouse mating was usually completed in 
about 20 minutes, and females rarely mated more than once. The females appeared to remain on or near food suitable for the larvae, but males were circulating rather freely.

\section{OVIPOSITION}

After the female has been fertilized egg laying may begin in a few hours, and in nearly all cases observed the first eggs were laid within 24 hours after mating. Observations showed that the female was somewhat sluggish for the first few days of her life, the time during which most of the eggs were deposited. Females rarely deposited any eggs before mating. In warehouses the eggs were laid either singly or in small clusters and preferably on or near tobacco. They were found on the burlap covering of Turkish tobacco bales, in the cracks of closely fitting staves of hogsheads, and on the tobacco leaves. When ovipositing on tobacco leaves in the laboratory the females usually placed their eggs along the midrib and larger veins (fig. 4). During the process of egg laying the moths were quiet, with the wings folded horizontally along the body and the legs somewhat apart. The tip of the ovipositor was pressed against the leaf and was beneath the wings, so it was difficult to observe the actual process of $\mathrm{eg} g$ laying. $\mathrm{Fe}$ males demonstrated a strong preference for ovipositing in the meshes of burlap or screen wire, particularly the latter.

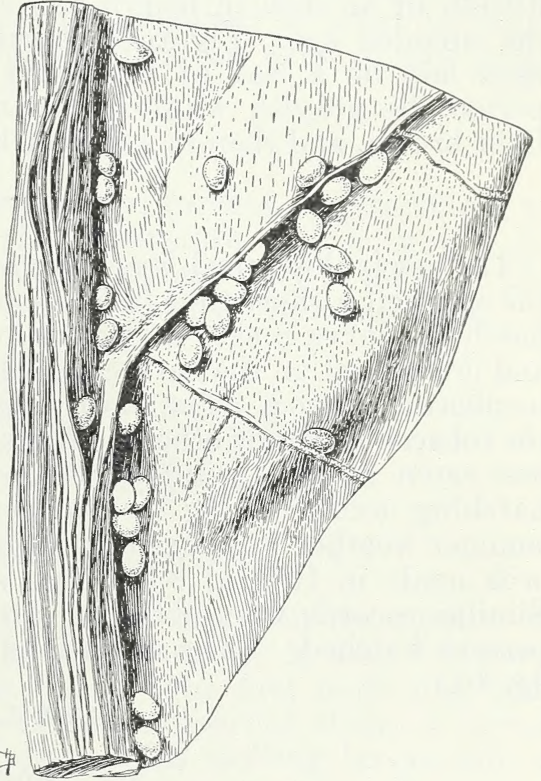

Figure 4.-Eggs of the tobacco moth showing a characteristic placing of the eggs along the midrib and veins of a tobacco leaf. $\times 10$.

The ovipositing moths do not feed but consume small quantities of water. The effect of imbibing water on the rate and number of egos laid was not determined in these studies. Norris (13, pp. 335-346), however, has recorded a study of the influence of water on the fecundity and longevity of moths of the genus Ephestia. The following statements by her are of interest:

Both the fecundity and longevity of $E$. elutella females are approximately doubled if the moths are allowed access to water. The actual reduction figure for fecundity of 47 percent is very slightly lower than that obtained in most of the experiments with $E$. cautella, but the smallness of the number of individuals concerned in this experiment makes it improbable that this is of any significance. Larger numbers of $E$. elutella were not available at the time of the experiment-the breeding of this species in captivity presenting considerable difficulty - and it was not thought necessary to repeat it at a later date as the result obtained was so very definite.

Moths rarely have access to water in tobacco warehouses; it is likely, however, that the moisture content of the tobacco or air influences the 
number of eggs laid, and this problem should receive further investigation.

\section{THE EGG}

The eggs have soft shells when freshly laid, and are covered with a glue which in most cases fastens them securely to the surface on which they were laid for the length of the incubation period. When eggs are pressed together in clusters they often dry into distorted shapes, as the shells harden in a few minutes after they are laid.

The eggs of the tobacco moth are elliptical and grayish white, and, when viewed through a binocular microscope, the shell appears to have a granular texture. They measure from one-fortieth to onefiftieth of an inch in length and can be seen on tobacco leaves with the unaided eye. Figure 4 shows a characteristic arrangement of eggs laid on a leaf of flue-cured tobacco. During the incubation period the grayish white of the newly deposited egg changes to a light brown, and then to a darker brown.

\section{HATCHING}

The newly developed larva of the tobacco moth can be seen through the eggshell a short time before hatching. When the egg is ready to hatch the larva makes a circular opening in the end of the eggshell and crawls out on the surface to which the egg is attached during the incubation period. The empty eggshells often remain attached to the tobacco leaves or other surfaces, retaining their original shape unless eaten by the young larvae. In spring and fall, most of the hatching occurs during the warmer parts of the day whereas in hot, summer weather it occurs to a large extent at night. Incubation records made in 1932 of 3,186 eggs showed that 69.2 percent hatched. Similar records were obtained during 1933 for 2,916 eggs, and 71.3 percent hatched. (For conditions of temperature and humidity see fig. 10.)

\section{THE LARVA}

HABITS

In the warehouses the larvae are active after emerging from the eggshells and crawl away without delay in search of food. The ease and speed with which they crawl indicate that young larvae are capable of migrating considerable distances in search of food. Feeding on tobacco leaves begins at once, provided the moisture content of the leaf is satisfactory. It became apparent early in the lifehistory studies that moisture in the tobacco leaves was a very important factor in the survival and growth of larvae. The ideal moisture content for the best growth on flue-cured tobacco is approximately 13 percent; detailed observations, however, demonstrated that larvae could survive in tobacco with as little as 10 percent moisture in the leaf. In small rearing containers in which portions of tobacco leaves were used as food, the moisture rapidly evaporated during exposure in the laboratory, and a heavy mortality of young larvae resulted. Feeding is rather voracious from the start; the young larvae eat the upper or lower cuticle of the leaf until about the first molt, after which the entire leaf between the larger veins and the midrib is con- 
sumed (fig. 1), the method of feeding being similar in some respects to that of leaf-eating caterpillars.

\section{CANNIBALISM}

When placed in confinement, tobacco moth larvae are cannibalistic. This habit is more pronounced with well-grown larvae, and occurs especially when the victims are weak or inactive from molting or at the time of pupation. The writers have often wondered why the tobacco moth did not increase more rapidly in the large stocks of flue-cured and Turkish tobacco stored in the eastern part of the United States. Although there is the possibility that cannibalism takes place in the warehouses, and that this serves as a check on the multiplication of the species, it was not observed to occur in hogsheads or bales of tobacco and probably does not exist to any great extent except in heavy infestations.

\section{RATE OF GROWTH}

The larrae showed a very uneven rate of growth despite efforts to provide uniform conditions of food, temperature, and moisture. As shown in table 1 , the period of development may rary as much as 130 days in different groups of larrae that hatched in the same week.

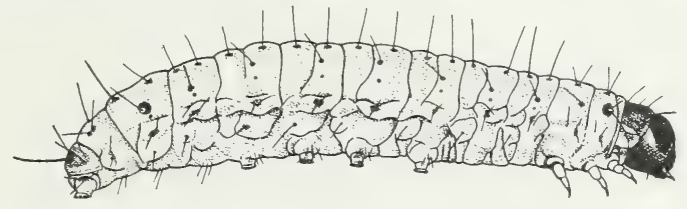

Figure 5.-Full-grown larva of the tobacco moth. $\times 6$.

The number of molts depends to a large extent on the quality of food and the rate of growth. The usual number is five, but some larvae were observed to molt nine times. The first molt may take place 4 days after hatching, and in the cases observed others occurred at intervals ranging from 2 to 20 days. The molting larvae spin a loose covering of silk in which particles of excrement or tobacco are entangled. In this partial protection the larvae remain while molting, which requires only a few hours under favorable conditions.

The larva is the most adaptable stage of the moth, it being able to resist starvation for long periods unfavorable for growth, and to change foods with ease, from tobacco to some other dried material, such as dry yeast, cacao beans, unbolted corn meal, or dried buttermilk. The larva was the only stage that passed the winter in unheated tobacco storages in southern Virginia. In 1932 a total of 433 larvae overwintered in the laboratory and the lengths of their larval periods were: Maximum, 354 days; minimum, 182 days; average. 259.7 days. In 1931 the larval periods for 430 overwintering individuals were: Maximum, 336 days; minimum. 209 days; average, 261.1 days. The mature larva is shown in figure 5.

THE PREPUPA

When larvae are fully grown (fig. 5) they seek a sheltered place for pupation, as explained under adult emergence on page 6. The $101216^{\circ}-37-2$ 
majority of the larvae observed constructed loosely woven cocoons (fig. 6), upon the completion of which they became sluggish and inactive. From less than a day in warm weather to a week or more during the cooler weather of spring and fall was consumed in the prepupal stage. The last larval skin was cast off and remained in the cocoon. In some instances larvae pupated naked, especially when low temperatures and poor-quality foods made conditions unfarorable for growth.

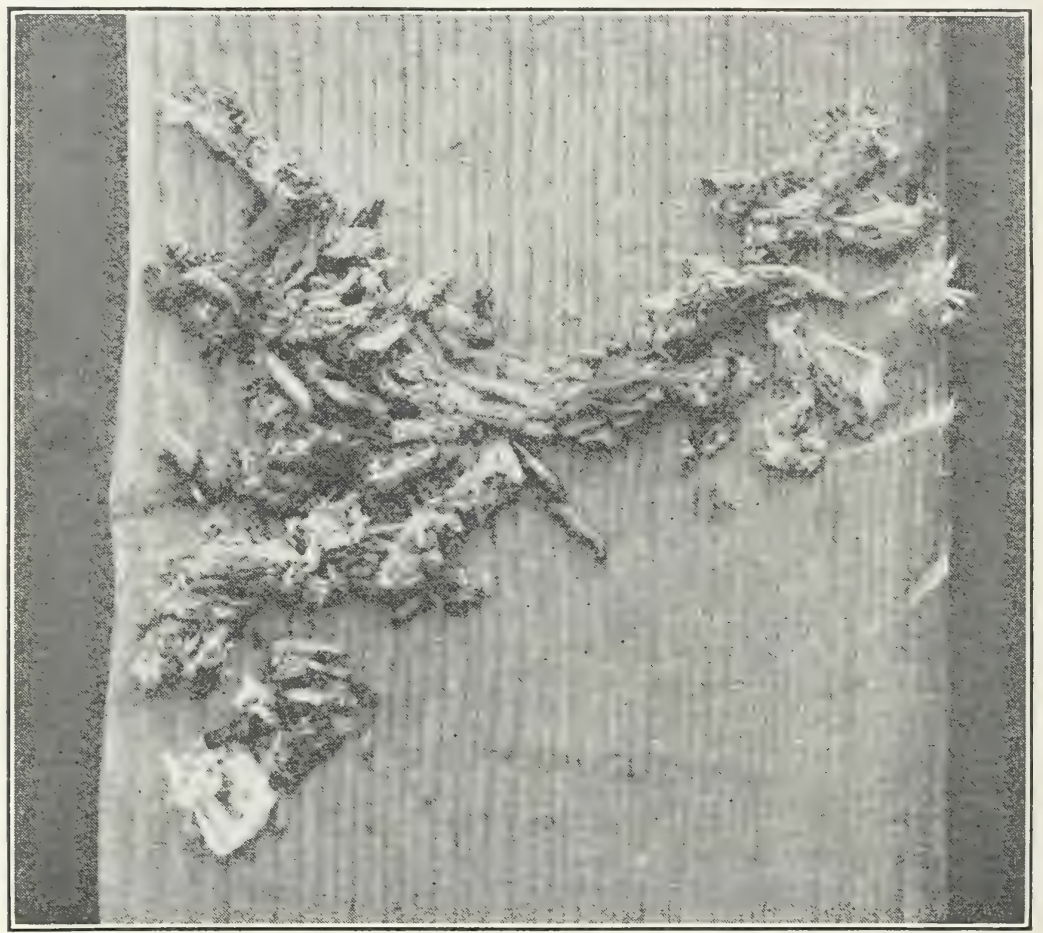

Figure 6.-Cocoons of the tobacco moth spun beneath a floor board of a tobacco warehouse for purposes of overwintering and pupation.

\section{THE PUPA}

The pupae are semiactive when disturbed, being able to wriggle the abdomen and roll about in the cocoon. Then removed from the cocoon or disturbed by prodding, they wriggle energetically. The tendency is for the disturbed pupae to squirm away from bright lights. They are light brown in color when newly formed, turning a darker brown with age (fig. 7).

The average of the pupal periods ranged from 5 days in hot summer weather to 25 days during the cool periods in spring and fall. Many hundreds of pupae that transformed late in the fall died during the winter. Several hundred infested hogsheads in unheated storages were examined by the writers late in the winter and no living pupae were found. The maximum length of the pupal period ob- 
served in the laboratory was 25 days. This occurred in October. and it is likely that this figure represents approximately the maximum duration of the pupal period obtaining in tobacco storages.

\section{SEASONAL HISTORY}

In the unheated warehouses in which the writers made their observations the tobacco moth passed the winter as one-fourth-grom to full-gromn larrae. Many of those that mere full-gromn had migrated to sheltered places about the buildings, but the undereloped larvae usually remained in the tobacco, where, during periods of warm weather, they were observed crawling in the tobacco leaves. It is possible that they did some feeding during such periods. The low winter temperatures experienced in Virginia and North Carolina during the period of these studies $\left(28^{\circ} \mathrm{F}\right.$. tobacco temperature and $9^{\circ}$ warehouse temperature) did not appear to reduce materially the larval population.

The full-grown larvae began to pupate in the tobacco warehouses in March, and the records show the earliest emergences to have been as follows: In 1931 , May 2 ; in 1932, April 24; in 1933, May 2; and in 1934 on April 26. The emergence of the spring brood proceeded at a rather slow rate until the advent of hot weather, approximately May 25.

In the laboratory this emergence covered a wide span of time-for example, in 1932 from April 21 to July 15, and in 1933 from April 14 to July 9. This long period was due in part to the fact that the larvae going into hibernation in the fall were of different ages, but to a greater extent to their uneven rate of growth. Although the period of emergence of the spring brood is extended there was a peak emergence at a date around which most of the brood appeared. This peak in the laboratory occurred about May 15 in 1932 and May 12 in 1933 (table 1). Observations showed that the peak of spring emergence in tobacco warehouses occurred approximately 10 days later than in the laboratory-on May 25 in 1932 and on May 22 in 1933 . The spring brood of moths mated and began egg laying soon after emergence.

There were two complete generations of the insect in tobacco warehouses and three periods of moth emergence each year (fig. 8). A small number of larvae of the first generation, approximately onehalf of those of the second, and all of those of the third passed through the winter and emerged the following spring. There were three dates in 1933 on which the peak of emergence was recorderl. riz. May 12 for spring-brood moths. July 22 for first-generation moths, and September 18 for moths of the second generation. These dates are likely to rary from year to gear with environment anci temperature. 


\section{LIFE-HISTORY STUDIES OF 1932 AND 1933}

Following previous studies (18) moths of the spring brood were collected from tobacco warehouses in Richmond in 1931, and laboratory rearings were obtained from these and a continuous record kept of the development of some of their progeny through the spring of 1934.

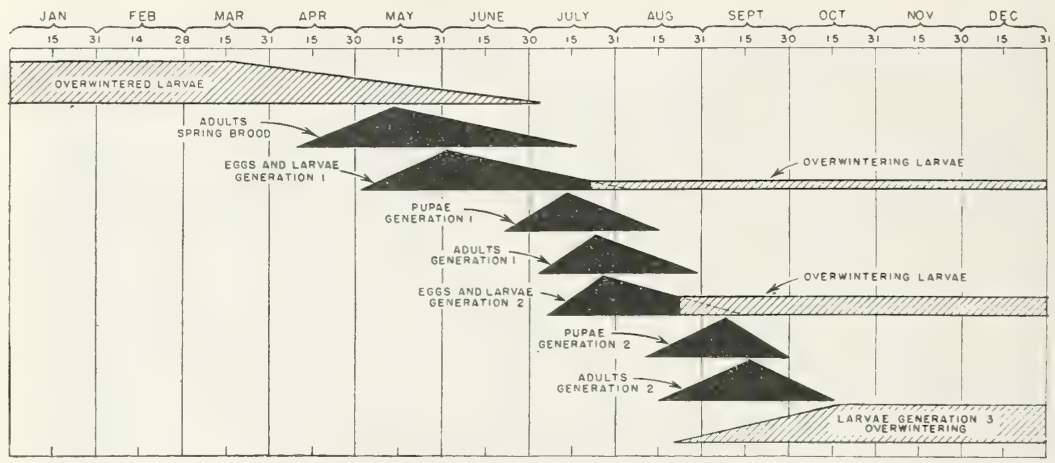

Figure 8.-Seasonal occurrences of the stages of the tobacco moth in Virginia and North Carolina, based on laboratory life-history studies and on observations made in tobacco warehouses, 1932 to 1934.

\section{METHODS AND APPARATUS}

To obtain egg-laying records pairs of moths were placed in individual glass vials in which were portions of leaves of flue-cured tobacco. The vials used (fig. 9) were 41/s inches high and 1 inch in diameter, and each was corered by a closely fitting metal cap. Every 24 hours the exposed pieces of tobacco were removed from the vials and fresh pieces substituted, and all eggs laid during the interval were counted with the aid of a binocular microscope. During incu-

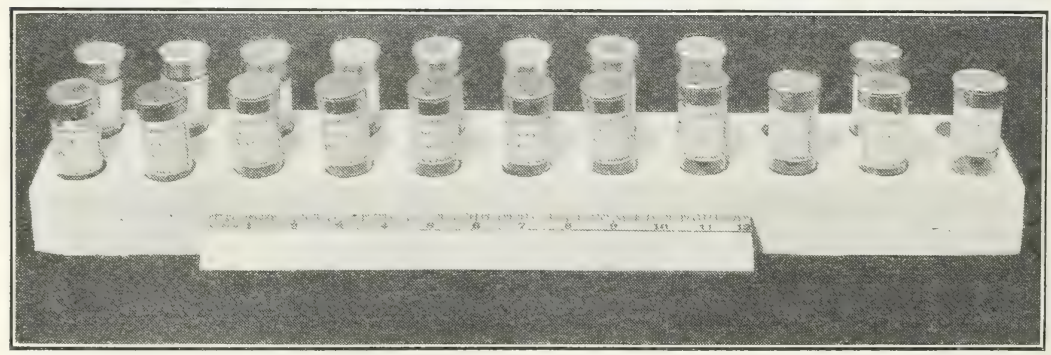

Figure 9.-Metal-capped glass vials used in oviposition studies on the tobacco moth.

bation the groups of eggs, usually attached to the leaves (fig. 4), were left in vials and examined daily for hatching.

When the eggs hatched, the young larvae were transferred individually from the vials and placed on tobacco in pasteboard pill boxes $13 / 4$ inches in diameter and three-fourths of an inch deep. These pill boxes were kept in large metal boxes that conserved the moisture, holding the moisture at about 13 percent while the larvas were developing. Portions of flue-cured tobacco leaves and parts of leaves 
that had been forced through a 48-mesh screen were added as food. In the studies of 1931 it was found that young larvae often experienced difficulty in feeding on tobacco leares low in moisture content. This was overcome by using screened tobacco, since this retained moisture for a longer time than pieces of unscreened tobacco leaves.

\section{SPRING EMERGENCE, 1932}

During November 1931, 452 larvae were placed in hibernation cages in the laboratory, and records of spring-brood emergence were obtained from these in 1932. Of this number, 430 survived and pupated. and 388 moths emerged. A total of 406 larvae survired the following winter and emerged in the spring of 1933. Records of emergence of spring-brood moths in the laboratory for 1932 and 1933 are given in table 1.

TABLE 1.-Records of emergence of the spring brood of the tobacco moth in 1932 and 19.33 in the laboratory, Richmond, Ta.

\begin{tabular}{|c|c|c|c|c|c|c|c|}
\hline \multirow{2}{*}{ Period of emergence ${ }^{1}$} & \multirow{2}{*}{\multicolumn{2}{|c|}{$\begin{array}{l}\text { Cumulatire } \\
\text { emergence }\end{array}$}} & \multicolumn{2}{|c|}{ Sex } & \multicolumn{2}{|c|}{$\begin{array}{l}\text { Egg-to-adult period } \\
\text { of moths }\end{array}$} & \multirow{2}{*}{$\begin{array}{c}\text { Mean } \\
\text { average } \\
\text { tempera- } \\
\text { ture of } \\
\text { emer- } \\
\text { gence } \\
\text { period }\end{array}$} \\
\hline & & & Male & Female & $\begin{array}{l}\text { Maxi- } \\
\text { mum }\end{array}$ & $\begin{array}{l}\text { Mini- } \\
\text { mum }\end{array}$ & \\
\hline $\begin{array}{l}\text { Apr. 21-28 } \\
\text { Apr. 28-May 5 } \\
\text { May 5-12 } \\
\text { May 12-19 } \\
\text { May 19-26. } \\
\text { May 26-June } 2 \\
\text { June 2-9 } \\
\text { June 9-16 } \\
\text { June 16-23 } \\
\text { June 23-30 } \\
\text { June 30-July } 7 \\
\text { July 7-14 } \\
\text { July } 15\end{array}$ & $\begin{array}{r}\text { Number } \\
4 \\
23 \\
160 \\
287 \\
342 \\
360 \\
373 \\
380 \\
383 \\
383 \\
386 \\
387 \\
388\end{array}$ & \begin{tabular}{r|} 
Percent \\
1.0 \\
5.9 \\
41.2 \\
74.0 \\
88.1 \\
92.8 \\
96.1 \\
97.9 \\
98.7 \\
98.7 \\
99.5 \\
99.7 \\
100.0
\end{tabular} & $\begin{array}{r}\text { Number } \\
1 \\
14 \\
71 \\
76 \\
23 \\
9 \\
6 \\
2 \\
1 \\
0 \\
2 \\
1 \\
1\end{array}$ & $\begin{array}{r}\text { Number } \\
3 \\
5 \\
66 \\
51 \\
32 \\
9 \\
7 \\
5 \\
2 \\
0 \\
1 \\
0 \\
0\end{array}$ & $\begin{array}{r}\text { Days } \\
287 \\
294 \\
321 \\
324 \\
331 \\
338 \\
326 \\
333 \\
317 \\
353 \\
358 \\
\end{array}$ & $\begin{array}{r}\text { Days } \\
264 \\
268 \\
260 \\
269 \\
273 \\
286 \\
286 \\
283 \\
295 \\
310 \\
358\end{array}$ & $\begin{array}{l}{ }^{\circ} F . \\
57 \\
66 \\
75 \\
70 \\
70 \\
73 \\
78 \\
75 \\
78 \\
82 \\
80 \\
80 \\
86\end{array}$ \\
\hline Total & 388 & $\ldots$ & 207 & 181 & 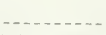 & & \\
\hline 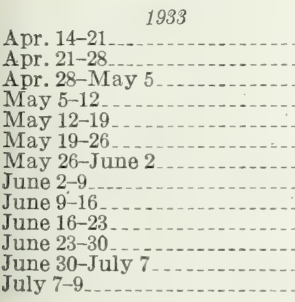 & $\begin{array}{r}4 \\
23 \\
115 \\
217 \\
312 \\
357 \\
364 \\
381 \\
390 \\
396 \\
403 \\
403 \\
406\end{array}$ & $\begin{array}{r}1.0 \\
5.7 \\
28.3 \\
53.4 \\
76.8 \\
87.9 \\
89.7 \\
93.8 \\
96.1 \\
97.5 \\
99.3 \\
99.3 \\
100.0\end{array}$ & $\begin{array}{r}3 \\
11 \\
52 \\
56 \\
36 \\
12 \\
6 \\
7 \\
6 \\
4 \\
5 \\
0 \\
2\end{array}$ & $\begin{array}{r}1 \\
8 \\
40 \\
46 \\
59 \\
33 \\
1 \\
10 \\
3 \\
2 \\
2 \\
0 \\
1\end{array}$ & $\begin{array}{l}352 \\
360 \\
364 \\
380 \\
373 \\
380 \\
282 \\
295 \\
298 \\
305 \\
305 \\
-279\end{array}$ & $\begin{array}{r}234 \\
241 \\
246 \\
251 \\
243 \\
265 \\
241 \\
239 \\
236 \\
258 \\
252 \\
273\end{array}$ & $\begin{array}{l}63 \\
61 \\
70 \\
68 \\
76 \\
77 \\
78 \\
7 \times \\
80 \\
78 \\
82 \\
82 \\
82\end{array}$ \\
\hline Total & 406 & & 200 & 206 & & & \\
\hline
\end{tabular}

1 Records were made durins the day, and those moths that emerged in the early part of the day were counted with one group and those emerging after the count were included in the following period.

As shown in table 1, the first emergence of spring-brood moths occurred on April 21 in 1932 and on April 14, or 1 week earlier, in 1933. On June 9, 1932, 96.1 percent had emerged, while on the same date in 1933, 93.8 percent of the brood had emerged. The generally warmer weather that prevailed in 1933 did not appear to affect greatly the rate of spring emergence, but it is likely that this factor was responsible for the emergence beginning 1 week earlier. Some of the 
larvae of spring-brood moths in 1933 had required more than a year to complete growth, the maximum being 380 days. The minimum developmental period, 234 days, for spring-brood moths occurred also in 1933.

\section{OVIPOSITION AND LONGEVITY}

In 1932, 87 pairs of spring-brood moths were mated and records obtained of egg deposition and longerity, and similar records were kept in 1933 of 18 mated pairs. The records of egg laying and longevity aro shown in table 2.

TABLE 2.-Oviposition and longevity records of mated pairs of tobacco moths of the spring brood in 1932 and 1933, in the laboratory, Richmomd, $\nabla a$.

\begin{tabular}{|c|c|c|c|c|c|c|c|}
\hline \multirow{2}{*}{ Period of emergence ${ }^{1}$} & \multirow{2}{*}{$\begin{array}{l}\text { Pairs of } \\
\text { moths }\end{array}$} & \multicolumn{3}{|c|}{ Eggs laid } & \multicolumn{2}{|c|}{$\begin{array}{l}\text { Average adult } \\
\text { longevity }\end{array}$} & \multirow{2}{*}{$\begin{array}{l}\text { A verage } \\
\text { mean } \\
\text { tempera- } \\
\text { ture for } \\
\text { emer- } \\
\text { gence } \\
\text { period }\end{array}$} \\
\hline & & $\begin{array}{l}\text { Maxi- } \\
\text { mum! }\end{array}$ & $\begin{array}{l}\text { Mini- } \\
\text { mum }\end{array}$ & Average & Males & Females & \\
\hline $\begin{array}{l}\text { Apr. } 21-28 \\
\text { Apr. } 28-\text { May } 5 \\
\text { May } 5-12 \\
\text { May } 12-19 \\
\text { May } 19-26 \\
\text { May } 26-J u n e ~ 2 \\
\text { June } 2-9 \\
\text { June } 9-16 \\
\text { June } 16-23\end{array}$ & $\begin{array}{r}\text { Number } \\
2 \\
6 \\
34 \\
23 \\
8 \\
4 \\
4 \\
4 \\
2\end{array}$ & $\begin{array}{r}\text { Number } \\
41 \\
108 \\
149 \\
134 \\
206 \\
75 \\
72 \\
93 \\
173\end{array}$ & $\begin{array}{r}\text { Number } \\
13 \\
14 \\
9 \\
16 \\
17 \\
27 \\
9 \\
24 \\
78\end{array}$ & $\begin{array}{r}\text { Number } \\
27.0 \\
65.5 \\
65.8 \\
57.7 \\
96.0 \\
49.0 \\
31.0 \\
60.0 \\
125.5\end{array}$ & $\begin{array}{l}\text { Days. } \\
\text { (2) } \\
6.6 \\
9.9 \\
8.6 \\
7.5 \\
5.0 \\
5.3 \\
7.0 \\
5.0\end{array}$ & $\begin{array}{r}\text { Days } \\
8.0 \\
8.3 \\
8.6 \\
9.7 \\
8.4 \\
8.0 \\
6.8 \\
7.8 \\
8.0\end{array}$ & $\begin{array}{r}\circ F . \\
57 \\
66 \\
75 \\
70 \\
70 \\
73 \\
78 \\
75 \\
78\end{array}$ \\
\hline Total & 87 & -- & 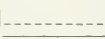 & & & & \\
\hline $\begin{array}{l}\text { Apr. 14-21 } 1933 \\
\text { Apr. 21-28 } \\
\text { 4pr. 28-May } 5 \\
\text { May 5-12 } \\
\text { May } 12-19 \\
\text { May 19-26 } \\
\text { May 26-June } 2 \\
\text { June 2-9 } \\
\text { July } 9\end{array}$ & $\begin{array}{l}1 \\
6 \\
1 \\
4 \\
1 \\
0 \\
0 \\
4 \\
1\end{array}$ & $\begin{array}{r}31 \\
80 \\
72 \\
260 \\
84 \\
153 \\
80\end{array}$ & $\begin{array}{r}31 \\
1 \\
72 \\
56 \\
84\end{array}$ & $\begin{array}{r}31.0 \\
40.8 \\
72.0 \\
132.0 \\
84.0\end{array}$ & $\begin{array}{l}{ }^{(2)} 7.5 \\
(2) \\
13.7 \\
9.0\end{array}$ & $\begin{array}{r}14.0 \\
8.2 \\
25.0 \\
12.8 \\
9.0\end{array}$ & $\begin{array}{l}63 \\
61 \\
70 \\
68 \\
76 \\
77 \\
78 \\
78 \\
85\end{array}$ \\
\hline Total & 18 & & & & & & \\
\hline
\end{tabular}

${ }_{1}$ Records were made during the day, and those moths that emerged in the early part of the day were counted with one group and those emerging after the count were included in the following period.

${ }_{2}$ The length of time the adult lived was not determined.

The greatest number of eggs obtained from a moih in the spring of 1932 was 206 (table 2), while in 1933 one female deposited 260 eggs. The writers are unable to give a satisfactory explanation for the great variation in the number of eggs laid by the moths on tobacco.

The maximum longerity of females in 1932 was 13 dars, and in 1930 one individual lived for the unusually long period of 25 days. The longest average period in 1932 of 9.7 days was recorded for 23 females that emerged during the period May 12 to 19, with an average mean temperature for the period of $70^{\circ} \mathrm{F}$. The ligher temperatures that prevailed in 1933 appeared not materially to affect the egg deposition and longevity of adults. The female that deposited 260 eggs in 1933 is considered exceptional, since this is by far the largest number deposited by an individual reared on tobacco in the laboratory.

The quality of cigarette-trpe tobacco on which moth larvae feed affects the rate of growth and the size of the adult insect. If given 
a choice, moths will select for oriposition those grades of tobacco high in sugar. Boringdon ( $4, p p .3,-42$ ) conducted food-selection experiments which shored that tobacco moths preferred to oriposit on flue-cured tobacco. This inrestigator used dark-fired tobacco in comparative tests and concluded that the toxic substances on leares of this type, such as formaldehyde, pyroligineous acid, and methyl alcohol, were probably responsible for the choice of the other type. The effect of the quality and grade of cured tobacco on the growth and reproduction of the tobacco moth is a problem which should receive further study.
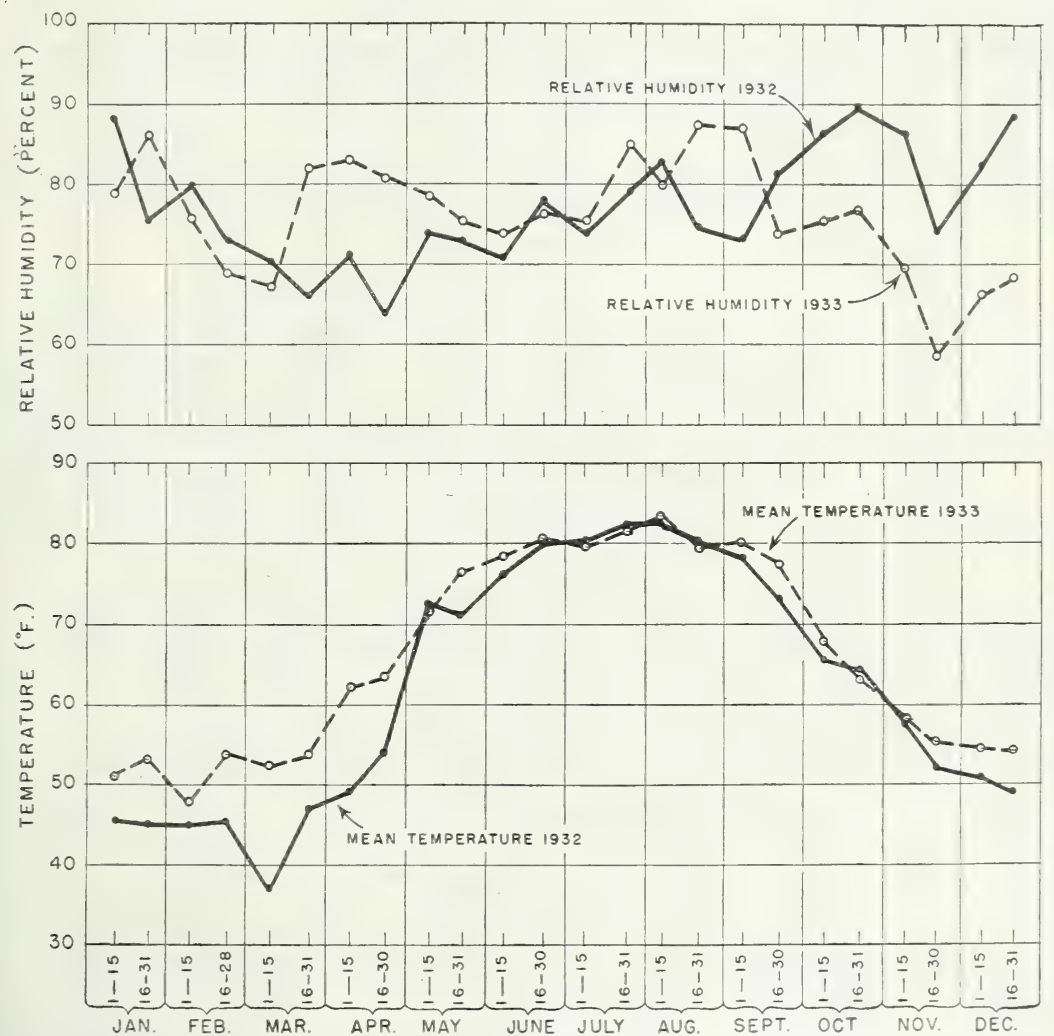

FigURE 10.-The relative humidity and mean temperature in the unheated laboratory at Richmond, Va., averaged for each semimonthly period of 1932 and 1933.

TEMPERATURE

Since a more rapid growth of the insects occurred in 1933 than in 1932. and this was apparently due to higher arerage temperatures, it is considered worth while here to discuss the temperatures that prerailed in those rears. In figure 10 are giren the mean temperatures and arerage relatice humidities for semimonthly periods in the laboratory during 1932 and 1933.

The temperature during the first 6 months of 1933 was considerabily higher than in 1932. This higher temperature, howerer, failed to affect materially the rate of emergence of spring-brood moths. 
(Table 1.) The higher temperature during April, May, and June in 1933 apparently accelerated the development periods and were responsible for the fact that a much larger number of individuals completed the third generation in that year. The higher temperatures prevailing in September and part of October also contributed to the growth of moths of the third generation. As shown by incubation records in table 3, first-generation eggs were laid 5 days earlier in 1933 whereas the second and third generations appeared 25 days and 49 days, respectively, earlier in 1933 than in 1932.

\section{INCUBATION PERIOD}

Incubation periods of eggs of the first, second, and third generations of moths were recorded in 1932 and 1933 and a summary of these records is shown in table 3.

TABLE 3.-Incubation periods of eggs of the tobacco moth in the laboratory, Richmond, Va., 1932 and 1933

FIRST GENERATION

\begin{tabular}{|c|c|c|c|c|c|c|c|c|c|}
\hline \multicolumn{5}{|c|}{1932} & \multicolumn{5}{|c|}{1933} \\
\hline \multirow{2}{*}{$\begin{array}{l}\text { Period eggs } \\
\text { were laid } 1\end{array}$} & \multirow{2}{*}{ Eggs } & \multicolumn{2}{|c|}{$\begin{array}{l}\text { Incubation } \\
\text { period }\end{array}$} & \multirow{2}{*}{$\begin{array}{l}\text { A ver- } \\
\text { age } \\
\text { mean } \\
\text { tem- } \\
\text { pera- } \\
\text { ture } \\
\text { for } \\
\text { period }\end{array}$} & \multirow{2}{*}{$\begin{array}{l}\text { Period eggs } \\
\text { were laid } 1\end{array}$} & \multirow{2}{*}{ Eggs } & \multicolumn{2}{|c|}{$\begin{array}{l}\text { Incubation } \\
\text { period }\end{array}$} & \multirow{2}{*}{$\begin{array}{l}\text { A ver- } \\
\text { age } \\
\text { mean } \\
\text { tem- } \\
\text { pera- } \\
\text { ture } \\
\text { for } \\
\text { period }\end{array}$} \\
\hline & & Range & $\begin{array}{c}\text { Weight- } \\
\text { ed aver- } \\
\text { age }\end{array}$ & & & & Range & $\begin{array}{l}\text { Weight- } \\
\text { ed aver- } \\
\text { age }\end{array}$ & \\
\hline 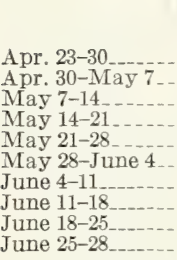 & $\begin{array}{r}\text { Num- } \\
\text { ber } \\
39 \\
319 \\
1,918 \\
1,648 \\
1,008 \\
233 \\
118 \\
240 \\
211 \\
34\end{array}$ & $\begin{array}{l}\text { Days } \\
10-12 \\
7-11 \\
8-14 \\
7-15 \\
6-12 \\
5-10 \\
5-8 \\
5-7 \\
5-6 \\
4-6\end{array}$ & \begin{tabular}{r|} 
Days \\
11.0 \\
7.9 \\
9.1 \\
8.6 \\
7.2 \\
7.1 \\
6.9 \\
5.9 \\
5.3 \\
4.8
\end{tabular} & $\begin{array}{l}{ }^{\circ} F . \\
56 \\
73 \\
72 \\
71 \\
74 \\
72 \\
77 \\
77 \\
78 \\
82\end{array}$ & $\begin{array}{l}\text { Apr. 18-25 } \\
\text { Apr. 25-May 2. } \\
\text { May 2-9 } \\
\text { May 9-16 } \\
\text { May 16-23 } \\
\text { May 23-30 } \\
\text { May 30-June 6 } \\
\text { June 6-13 } \\
\text { June 13-15 }\end{array}$ & $\begin{array}{r}\text { Num- } \\
\text { ber } \\
31 \\
270 \\
764 \\
659 \\
657 \\
0 \\
0 \\
503 \\
32\end{array}$ & $\begin{array}{r}\text { Days } \\
9-12 \\
8-10 \\
8-10 \\
5-10 \\
6-9 \\
-4-10 \\
7-9\end{array}$ & $\begin{array}{r}\text { Days } \\
11.0 \\
8.6 \\
8.8 \\
6.3 \\
6.9 \\
5.4 \\
8.1\end{array}$ & $\begin{array}{r}{ }^{\circ} F . \\
60 \\
67 \\
69 \\
75 \\
74 \\
80 \\
74 \\
84 \\
75\end{array}$ \\
\hline
\end{tabular}

SECOND GENERATION

\begin{tabular}{|c|c|c|c|c|c|c|c|c|c|}
\hline $\begin{array}{l}\text { July } 20-27 \\
\text { July } 27-\text { Aug. } 3 \\
\text { Aug. } 3-10 \\
\text { Aug. } 10-17 \\
\text { Aug. } 17-24 \\
\text { Aug. } 24-31 \\
\text { Aug. } 31-\text { Sept. } 7 \\
\text { Sept. } 7-14 \\
\text { Sept. 14-21 } \\
\text { Sept. } 21-28 \\
\text { Sept. } 28-\text { Oct. } 5 \\
\text { Oct. } 5-12 \\
\text { Oct. } 12-18\end{array}$ & $\begin{array}{r}618 \\
453 \\
397 \\
334 \\
484 \\
394 \\
158 \\
103 \\
125 \\
0 \\
16 \\
77 \\
27\end{array}$ & $\begin{array}{r}4-8 \\
4-7 \\
4-7 \\
4-7 \\
5-8 \\
4-6 \\
4-7 \\
5-7 \\
5-7 \\
-12-13 \\
10-12 \\
8-10\end{array}$ & $\begin{array}{r}5.2 \\
4.9 \\
4.1 \\
5.0 \\
6.3 \\
4.4 \\
5.5 \\
6.6 \\
6.1 \\
12.5 \\
11.5 \\
8.3\end{array}$ & $\begin{array}{l}83 \\
82 \\
84 \\
81 \\
78 \\
83 \\
86 \\
73 \\
75 \\
74 \\
69 \\
68 \\
62\end{array}$ & $\begin{array}{l}\text { June } 25-\text { July } 2 \\
\text { July } 2-9 \\
\text { July } 9-16 \\
\text { July } 16-23 \\
\text { July } 23-30 \\
\text { July } 30-\text { Aug. } 6 \\
\text { Aug. } 6-13 \\
\text { Aug. } 13-20 \\
\text { Aug. } 20-26\end{array}$ & $\begin{array}{r}91 \\
896 \\
2,838 \\
981 \\
62 \\
0 \\
164 \\
222 \\
83\end{array}$ & $\begin{array}{l}3-4 \\
4-6 \\
5-9 \\
3-7 \\
4-5 \\
4-6 \\
4-7 \\
4-7\end{array}$ & $\begin{array}{r}3.5 \\
4.8 \\
5.7 \\
4.5 \\
4.3 \\
-5.0 \\
5.2 \\
4.4\end{array}$ & $\begin{array}{l}84 \\
80 \\
78 \\
82 \\
83 \\
84 \\
81 \\
81 \\
80\end{array}$ \\
\hline
\end{tabular}

THIRD GENERATION

\begin{tabular}{|c|c|c|c|c|c|c|c|c|c|}
\hline Oct. 9-18 & 90 & $8-14$ & 10.8 & 63 & $\begin{array}{l}\text { Aug. 21-28 } \\
\text { Aug. } 28-\text { Sept. } 4 \\
\text { Sept. } 4-11 \\
\text { Sept. 11-18 }\end{array}$ & $\begin{array}{l}373 \\
129 \\
155 \\
209\end{array}$ & $\begin{array}{l}4-7 \\
5-6 \\
4-6 \\
4-7\end{array}$ & $\begin{array}{l}4.8 \\
5.5 \\
4.6 \\
5.9\end{array}$ & $\begin{array}{l}80 \\
78 \\
82 \\
79\end{array}$ \\
\hline
\end{tabular}

${ }^{1}$ Records were made during the day, and those eggs that were laid in the early part of the day were counted with one group and those laid after the count were included in the following period. 
The extreme incubation periods among 5,768 eggs of first-generation moths in 1932 were 15 and $t$ days and the shortest average period was 4.8 days. In 1933 with higher temperatures prevailing (fig. 10) the maximum hatching period in 2.916 eggs was 12 days and the minimum period 4 days. The maximum and minimum hatching periods of the second generation in 3,186 eggs in 1932 were 13 and $t$ days, respectively. Higher temperatures prevailed in 1933 during the period covered by the second generation, and the maximum and minimum incubation periods for 5,337 eggs were 9 and 3 days, respectively. It should be pointed out, however, that second-generation moths continued to emerge in 1932 until the middle of October, whereas in 1933 the last emergence occurred approximately August 26 (table 3). The average hatching periods of eggs laid in each generation for the 2-year studies, excluding eggs laid by females emerging in October 1932, were approximately the same. Only a small number of third-generation moths emerged, and many second-generation larvae overwintered to emerge as spring-brood moths.

\section{LARVAL PERIOD}

The maximum and minimum larval periods of the moths of the first and second generations in 1932 and 1933 are given in table $t$. The higher temperatures which prevailed in May and June 1933 caused larvae of the first generation to complete development more rapidly than the corresponding generation in 1932 .

TABLE 4.-Larval periods of the tobacco moth in the laboratory, Richmond, $T$ a., 1932 and 1933

FIRST GENERATION

\begin{tabular}{|c|c|c|c|c|c|c|c|c|c|}
\hline \multicolumn{5}{|c|}{1932} & \multicolumn{5}{|c|}{1933} \\
\hline \multirow{2}{*}{$\begin{array}{l}\text { Period of } \\
\text { hatching }{ }^{1}\end{array}$} & \multirow{2}{*}{ Larvae } & \multicolumn{2}{|c|}{$\begin{array}{l}\text { Length of larval } \\
\text { period }\end{array}$} & \multirow{2}{*}{$\begin{array}{l}\text { Aver- } \\
\text { age } \\
\text { mean } \\
\text { temper- } \\
\text { ature } \\
\text { for } \\
\text { larval } \\
\text { period }\end{array}$} & \multirow{2}{*}{$\begin{array}{l}\text { Period of } \\
\text { hatching } 1\end{array}$} & \multirow[b]{2}{*}{ Larvae } & \multicolumn{2}{|c|}{$\begin{array}{l}\text { Length of larval } \\
\text { period }\end{array}$} & \multirow{2}{*}{$\begin{array}{l}\text { Aver- } \\
\text { age } \\
\text { mean } \\
\text { temper- } \\
\text { ature } \\
\text { for } \\
\text { larval } \\
\text { period }\end{array}$} \\
\hline & & Range & $\begin{array}{l}\text { Weighted } \\
\text { average }\end{array}$ & & & & Range & $\begin{array}{c}\text { Weighted } \\
\text { average }\end{array}$ & \\
\hline $\begin{array}{l}\text { May 4-11... } \\
\text { May 11-18 } \\
\text { May 18-25.. } \\
\text { May 25-June } 1 \\
\text { June 1-8 } \\
\text { June 8-11 }\end{array}$ & $\begin{array}{c}\text { Number } \\
20 \\
41 \\
125 \\
51 \\
15 \\
3\end{array}$ & $\begin{array}{l}\text { Days } \\
59-101 \\
48-128 \\
39-118 \\
44-117 \\
46-104 \\
40-49\end{array}$ & \begin{tabular}{r|} 
Days \\
77.2 \\
78.4 \\
75.0 \\
74.3 \\
69.5 \\
43.3
\end{tabular} & $\begin{array}{r}{ }^{\circ} F . \\
76 \\
70 \\
69 \\
73 \\
77 \\
74\end{array}$ & $\begin{array}{l}\text { Apr. 30-May } 7 \\
\text { May 7-14. } \\
\text { May 14-21 } \\
\text { May 21-28... } \\
\text { May 28-June } 4 \\
\text { June 4-11 } \\
\text { June 11-18 } \\
\text { June 19 }\end{array}$ & $\begin{array}{r}\text { Number } \\
62 \\
185 \\
250 \\
316 \\
0 \\
0 \\
98 \\
6\end{array}$ & $\begin{array}{r}\text { Days } \\
35-77 \\
34-74 \\
30-72 \\
29-75 \\
---- \\
32-59 \\
37-52\end{array}$ & \begin{tabular}{r}
\multicolumn{1}{c}{ Days } \\
51.1 \\
52.2 \\
46.5 \\
43.1 \\
\hdashline 40.9 \\
42.8
\end{tabular} & $\begin{array}{r}{ }^{\circ} F . \\
70 \\
72 \\
75 \\
80 \\
74 \\
83 \\
76 \\
76\end{array}$ \\
\hline
\end{tabular}

SECOND GENERATION

\begin{tabular}{|c|c|c|c|c|c|c|c|c|c|}
\hline Aug. 14-20_... & 5 & $37-49$ & 44. 6 & 80 & $\begin{array}{l}\text { June 29-July 6. } \\
\text { July 6-13 } \\
\text { July } 13-20 \\
\text { July } 20-22\end{array}$ & $\begin{array}{r}4 \\
4 \\
64 \\
4\end{array}$ & $\begin{array}{l}25-35 \\
32-48 \\
23-66 \\
35-48\end{array}$ & $\begin{array}{l}31.5 \\
37.0 \\
35.3 \\
41.0\end{array}$ & $\begin{array}{l}83 \\
81 \\
78 \\
83\end{array}$ \\
\hline
\end{tabular}

1 Records were made during the day, and the larvae that emerged in the early part of the day were counted with one group and those emerging after the count were included in the following period. $101216^{\circ}-37-3$ 
In 1932 larvae of the first generation began hatching May 4, and in 1933 on April 30. The maximum and minimum developmental periods for 255 larvae of the first generation were 128 and 39 days, respectively. In 1933 these periods among 917 larvae were 77 and 29 days, respectively. The average larval periods of the second generation also were slightly shorter in 1933, when higher temperatures prevailed. As stated previously, however, the variation in the rate of growth of tobacco moth larvae cannot be satisfactorily explained on the basis of temperature and quality of food alone.

\section{PUPAL PERIOD}

The maximum and minimum pupal periods for the first and second generations in 1932 and 1933 are given in table 5.

TABLE 5.-Pupal periods of the tobacco moth in the laboratory, Richmond, Va., 1932 and 1933

FIRST GENERATION

\begin{tabular}{|c|c|c|c|c|c|c|c|c|c|}
\hline \multirow{3}{*}{$\begin{array}{l}\text { Period of enter- } \\
\text { ing pupation }{ }^{1}\end{array}$} & \multicolumn{3}{|c|}{1932} & & \multicolumn{5}{|c|}{1933} \\
\hline & \multirow{2}{*}{ Pupae } & \multicolumn{2}{|c|}{$\begin{array}{l}\text { Length of pupal } \\
\text { period }\end{array}$} & \multirow{2}{*}{$\begin{array}{l}\text { Aver- } \\
\text { age } \\
\text { mean } \\
\text { temper- } \\
\text { ature } \\
\text { for } \\
\text { pupal } \\
\text { period }\end{array}$} & \multirow{2}{*}{$\begin{array}{l}\text { Period of enter- } \\
\text { ing pupation }{ }^{1}\end{array}$} & \multirow{2}{*}{ Pupae } & \multicolumn{2}{|c|}{$\begin{array}{l}\text { Length of pupal } \\
\text { period }\end{array}$} & \multirow{2}{*}{$\begin{array}{l}\text { Aver- } \\
\text { age } \\
\text { mean } \\
\text { temper- } \\
\text { ature } \\
\text { for } \\
\text { pupal } \\
\text { period }\end{array}$} \\
\hline & & Range & $\begin{array}{c}\text { Weight- } \\
\text { ed aver- } \\
\text { age }\end{array}$ & & & & Range & $\begin{array}{c}\text { Weight- } \\
\text { ed aver- } \\
\text { age }\end{array}$ & \\
\hline $\begin{array}{l}\text { June } 27-\text { July } 4 .- \\
\text { July } 4-11 \\
\text { July } 11-18 \\
\text { July } 18-25 \\
\text { July } 25-\text { Aug. } 1 .- \\
\text { Aug. } 1-8 \\
\text { Aug. } 8-15 \\
\text { Aug. } 15-22 \\
\text { Aug. } 22-29 \\
\text { Aug. } 29-\text { Sept. } 5 \\
\text { Sept. } 5-12 \\
\text { Sept. } 12-19 \\
\text { Sept. } 19-22 \\
\end{array}$ & $\begin{array}{r}\text { Num- } \\
\text { ber } \\
3 \\
19 \\
23 \\
38 \\
28 \\
40 \\
45 \\
22 \\
16 \\
9 \\
5 \\
6 \\
1\end{array}$ & $\begin{array}{r}\text { Days } \\
11-12 \\
6-12 \\
8-12 \\
6-12 \\
9-12 \\
5-12 \\
8-14 \\
11-13 \\
8-11 \\
10-16 \\
10-16 \\
14-23 \\
25\end{array}$ & $\begin{array}{r}\text { Days } \\
11.5 \\
10.3 \\
10.8 \\
10.3 \\
10.6 \\
10.2 \\
11.6 \\
11.9 \\
9.5 \\
12.2 \\
13.9 \\
17.8 \\
25.0\end{array}$ & $\begin{array}{r}{ }^{\circ} F . \\
82 \\
79 \\
83 \\
85 \\
82 \\
83 \\
82 \\
79 \\
80 \\
87 \\
75 \\
75 \\
77\end{array}$ & $\begin{array}{l}\text { June } 8-15 \\
\text { June } 15-22 \\
\text { June } 22-29 \\
\text { June } 29-\text { July } 6 \\
\text { July } 6-13 \\
\text { July } 13-20 \\
\text { July } 20-27 \\
\text { July } 27-\text { Aug. } 3 \\
\text { Aug. } 3-10 \\
\text { Aug. } 10-14 \\
\end{array}$ & $\begin{array}{c}\text { Num- } \\
\text { ber } \\
16 \\
24 \\
111 \\
389 \\
206 \\
31 \\
61 \\
27 \\
5 \\
4\end{array}$ & $\begin{array}{r}\text { Days } \\
12-14 \\
10-12 \\
8-13 \\
9-15 \\
11-15 \\
10-13 \\
9-12 \\
8-13 \\
11-12 \\
8-12\end{array}$ & $\begin{array}{r}\text { Days } \\
12.9 \\
11.1 \\
10.4 \\
11.1 \\
12.1 \\
11.1 \\
10.4 \\
11.1 \\
11.4 \\
10.3\end{array}$ & $\begin{array}{r}{ }^{\circ} F . \\
82 \\
76 \\
82 \\
83 \\
81 \\
78 \\
84 \\
84 \\
80 \\
84\end{array}$ \\
\hline
\end{tabular}

SECOND GENERATION

\begin{tabular}{|c|c|c|c|c|c|c|c|c|c|}
\hline $\begin{array}{l}\text { Sept. } 20-27 \\
\text { Sept. } 27 \text {-Oct. } 4 \\
\text { Oct. } 4-8\end{array}$ & $\begin{array}{l}2 \\
1 \\
2\end{array}$ & $\begin{array}{r}11-14 \\
15 \\
9-25\end{array}$ & $\begin{array}{l}12.5 \\
15.0 \\
17.0\end{array}$ & $\begin{array}{l}75 \\
68 \\
71\end{array}$ & $\begin{array}{l}\text { July 24-31 } \\
\text { July 31-Aug. } 7 \\
\text { Aug. 7-14 } \\
\text { Aug. 14-21 } \\
\text { Aug. 21-28 } \\
\text { Aug. 28-Sept. } 4 \\
\text { Sept. } 4-11 \\
\text { Sept. 11-17 }\end{array}$ & $\begin{array}{r}1 \\
5 \\
16 \\
27 \\
15 \\
9 \\
2 \\
1\end{array}$ & $\begin{array}{r}10 \\
9-12 \\
9-12 \\
8-14 \\
10-14 \\
10-12 \\
11 \\
15\end{array}$ & $\begin{array}{l}10.0 \\
11.1 \\
10.9 \\
11.7 \\
12.5 \\
10.9 \\
11.0 \\
15.0\end{array}$ & $\begin{array}{l}82 \\
84 \\
83 \\
81 \\
80 \\
78 \\
82 \\
78\end{array}$ \\
\hline
\end{tabular}

1 Records were made during the day, and those larvae that pupated in the early part of the day were counted with one group and those pupating after the count were included in the following period.

For the first generation the maximum and minimum pupal periods for 255 pupae in 1932 were 25 and 5 days, respectively. In 1933 the maximum and minimum periods for 874 pupae were 15 and 8 days, respectively (table 5). The shorter periods in 1933 were probably due to the slightly higher temperatures which prevailed. The length of the pupal period increased at lower temperatures and was shortened by high temperatures. 


\section{LENGTH OF LIFE CYCLE}

The egg-to-adult period of the tobacco moth showed a wide range, which was due for the most part to the uneven rate of growth of the larvae. The maximum and minimum periods for individuals of the first and second generations which completed growth in 1932 and 1933 are given in table 6 .

TABLE 6.-Egg-to-adult periods of the tobacco moth in the laboratory, Richmond, Va., 1932 and 1933

FIRST GENERATION

\begin{tabular}{|c|c|c|c|c|c|c|c|c|c|}
\hline \multicolumn{5}{|c|}{1932} & \multicolumn{5}{|c|}{1933} \\
\hline \multirow{2}{*}{$\begin{array}{l}\text { Period eggs were } \\
\text { laid }^{1}\end{array}$} & \multirow{2}{*}{$\begin{array}{c}\text { Adults } \\
\text { pro- } \\
\text { duced }\end{array}$} & \multicolumn{2}{|c|}{$\begin{array}{l}\text { Length of egg-to- } \\
\text { adult period }\end{array}$} & \multirow{2}{*}{$\begin{array}{l}\text { Averege } \\
\text { mean } \\
\text { temper- } \\
\text { ature } \\
\text { for de- } \\
\text { velop- } \\
\text { mental } \\
\text { period }\end{array}$} & \multirow{2}{*}{$\begin{array}{l}\text { Period eggs were } \\
\text { laid } 1\end{array}$} & \multirow{2}{*}{$\begin{array}{c}\text { Adults } \\
\text { pro- } \\
\text { duced }\end{array}$} & \multicolumn{2}{|c|}{$\begin{array}{l}\text { Length of egg-to- } \\
\text { adult period }\end{array}$} & \multirow{2}{*}{$\begin{array}{l}\text { Average } \\
\text { mean } \\
\text { temper- } \\
\text { ature } \\
\text { for de- } \\
\text { velop- } \\
\text { mental } \\
\text { period }\end{array}$} \\
\hline & & Range & $\begin{array}{l}\text { Weight- } \\
\text { ed aver- } \\
\text { age }\end{array}$ & & & & Range & $\begin{array}{l}\text { Weight- } \\
\text { ed aver- } \\
\text { age }\end{array}$ & \\
\hline $\begin{array}{l}\text { Apr. 22-29 } \\
\text { Apr. 29-May 6. } \\
\text { May 6-13 } \\
\text { May 13-20 } \\
\text { May 20-27.- } \\
\text { May 27-June 2 }\end{array}$ & $\begin{array}{r}\text { Number } \\
16 \\
10 \\
151 \\
26 \\
42 \\
10\end{array}$ & $\begin{array}{l}\text { Days } \\
82-123 \\
81-152 \\
58-144 \\
66-151 \\
63-134 \\
59-133\end{array}$ & $\begin{array}{r}\text { Days } \\
94.6 \\
102.7 \\
93.9 \\
102.7 \\
88.2 \\
79.0\end{array}$ & $\begin{array}{r}{ }^{\circ} F . \\
56 \\
70 \\
74 \\
70 \\
72 \\
73\end{array}$ & 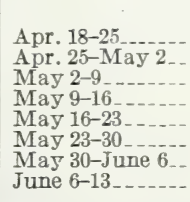 & \begin{tabular}{|r|} 
Number \\
26 \\
88 \\
311 \\
99 \\
275 \\
0 \\
0 \\
95
\end{tabular} & $\begin{array}{r}\text { Days } \\
62-123 \\
55-97 \\
52-93 \\
50-93 \\
46-77 \\
-49-75\end{array}$ & $\begin{array}{r}\text { Days } \\
71.3 \\
75.6 \\
70.3 \\
65.9 \\
59.4 \\
60.3\end{array}$ & $\begin{array}{r}{ }^{\circ} F . \\
60 \\
67 \\
69 \\
75 \\
74 \\
80 \\
74 \\
84\end{array}$ \\
\hline
\end{tabular}

SECOND GENERATION

\begin{tabular}{|c|c|c|c|c|c|c|c|c|c|}
\hline Aug. 9-14_..... & 5 & $54-79$ & 64.0 & 83 & $\begin{array}{l}\text { June 25-July } 1 \\
\text { July 1-8 } \\
\text { July } 8-15 \\
\text { July } 15-16\end{array}$ & $\begin{array}{r}5 \\
32 \\
46 \\
1\end{array}$ & $\begin{array}{r}39-53 \\
40-63 \\
44-85 \\
62\end{array}$ & $\begin{array}{l}47.6 \\
47.5 \\
54.3 \\
62.0\end{array}$ & $\begin{array}{l}82 \\
82 \\
83 \\
80\end{array}$ \\
\hline
\end{tabular}

1 Records were made during the day, and those eggs that were laid in the early part of the day were counted with one group and those laid after the count were included in the following period.

The rearings included in table 6 were exposed to higher temperatures in 1933, and this is in part responsible for more rapid development than shown in those of 1932 . The maximum and minimum developmental periods of 255 moths of the first generation in 1932 were 152 and 58 days, respectively. In 1933 the range for 894 moths was from 123 to 46 days. This more rapid growth in 1933 allowed 84 moths of the second generation to be reared, whereas in 1932 only 5 second-generation moths completed development. The lowest average egg-to-adult period, 47.5 days, for a group was for 32 moths that hatched during the interval July 1 to 8, 1933.

Observations made in tobacco storage warehouses in Virginia and North Carolina showed that the life cycle of the moth was approximately the same as in the laboratory. Spring emergence began usually from 7 to 10 days later in warehouses, owing to the longer time required for the temperature of bales and hogsheads of stored tobacco to rise. This lag in seasonal occurrence between laboratory and storage-reared moths is equalized in the fall, since the temperature of bales and hogsheads drops more slowly than the temperature of laboratory rearing containers. 
In order to show graphically the seasonal occurrence of the tobacco moth in 1932 and 1933 the data are presented in figure 8. The spring brood of moths, which is composed of a small percentage of the firstgeneration larvae, approximately 50 percent of the second, and all of the third of the preceding year began pupating approximately March 15, and emergence began approximately April 10. These dates are based upon laboratory life-history studies and many observations made in tobacco factories and warehouses during the period 1932 to 1934 in Virginia and North Carolina.

\section{CONTROL}

\section{NATURAL ENEMIES}

The tobacco moth has an important enemy in the small braconid parasite Microbracon hebetor (Say) (fig. 11). The sting of this small wasplike insect in a well-grown larva of the moth results in

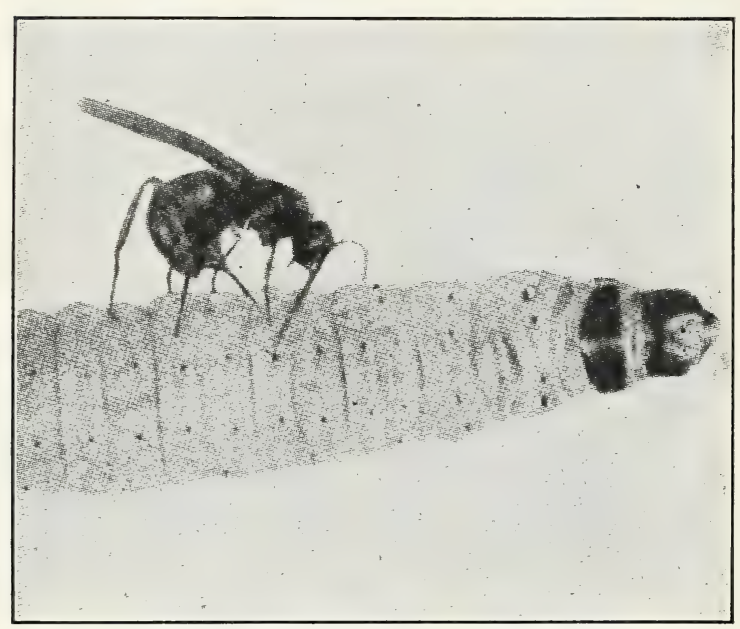

Figure 11.-The parasite Microbracon hebetor in the act of stinging a larva of the Mediterranean flour moth, Ephestia kuehniella. $\times 10$. complete paralysis of the larva in a few minutes. Eggs are then deposited be. neath or attached to the body of the host larva. These eggs hatch in about 2 days, when the temperature is above $70^{\circ}$ $\mathrm{F}$, and the young parasite grubs feed voraciously on the body of the moth larva. A total of 1,900 egg - to - adult rearings of the parasite were made in the laboratory, grown larvae of the tobacco moth being used
longevity were comas hosts, and records of egg deposition and longevity were com-
pleted for 14 females. A summary of these records shows the following averages: Incubation period 2 days, larval period 3.4 days, pupal period 5.2 days, egg-to-adult period 14.5 days. The highest number of eggs obtained from one female parasite was 517 and the lowest was 96. The average of the 14 females was 323 eggs each. The temperatures ranged from $65^{\circ}$ to $85^{\circ}$ during the time the foregoing records were being obtained. The shortest egg-to-adult period recorded for the tobacco moth was 39 days (table 6). It is estimated that under favorable conditions from two and one-half to three generations of this Microbracon will develop for each generation of the tobacco moth, and that on the average the parasite will reproduce at approximately three times the rate of the moth. These factors would appear to give the parasite a tremendous advantage in tobacco stor- 
ages, but the writers have been unable thus far to devise a satisfactory system of measuring the factors which apparently reduce the effectiveness of the parasite.

Observations in tobacco warehouses showed that these parasites overwinter as adults and pupae at or near the surface of hogsheads or bales of tobacco, and in cracks of walls or ceilings. These locations exposed the insect to the lowest temperatures in winter, and this was believed to be a factor of importance in reducing the population. In some warehouses infested by the tobacco moth no parasites were observed during the development of the first-generation larvae, but by September 15 they had increased to a point where thousands were seen on the surfaces of the tobacco and on windows of the warehouse. The individuals crawling on the closed windows were probably attempting to escape because of a shortage of host larvae. Experiments with light traps show the adult parasites to be positively phototropic but only to a small degree.

The other natural enemies of the tobacco moth observed in warehouses were mites of the genus Laelaps, which attach themselves to adults, and a spider, Theridion tepidariorum Koch, which sometimes constructs considerable webbing in which hundreds of moths are captured and destroyed. Neither the mites nor the spiders, however. have been observed to be of material aid in controlling moth infestations.

\section{TEMPERATURE}

The conclusion was reached, based on many observations in warehouses, that overwintering larvae of the tobacco moth can withstand the low temperatures occurring in winter in Virginia and the Carolinas without heavy mortality. Therefore low temperatures in storage warehouses cannot be considered as a natural control of hibernating moth larvae.

\section{ARTIFICIAL CONTROL IN CLOSED STORAGE}

\section{INSECT TRAPS}

Traps in which a combination of suction and light is used were tested in tobacco warehouses against the adults of the tobacco moth. These traps have proved ineffective, as shown by experiments of Reed et al. (19, p. 12), and cannot be recommended for use in warehouses against the insect.

\section{PERIODIC ATMOSPHERIC FUMIGATION}

From 1930 to 1932 the writers carried out fumigation experiments at atmospheric pressure in tobacco warehouses for the control of the tobacco moth. Hydrocyanic acid was used in the experiments, at dosages ranging from 4 to 24 ounces per 1,000 cubic feet, with exposures ranging from 12 to 72 hours. During the early stages of the work in 1930, it became apparent that if satisfactory results were to be obtained from the fumigation of warehouses, care must be exercised in sealing the infested buildings $(1, p .6)$. and in many instances fumigations must be repeated at intervals. 


\section{PREPARATION OF WAREHOUSES FOR FUMIGATION}

The infested warehouses (figs. 12 and 13) were equipped with the standard $1 / 4$-inch copper pipes and small disk spray nozzles for distributing the hydrocyanic acid to all parts of the building. The small copper pipes entered through a hole in the wall near a conrenient door or platform and were attached to the wall or ceiling in accordance with a plan to distribute the gas throughout the space to be fumigated. One small disk-type spray nozzle was installed for each 20,000 to 30,000 cubic feet of storage space. This system of pipes and nozzles enabled the gas to be introduced into the warehouses from the outside. The warehouses were filled with hogsheads. of flue-cured tobacco which were stacked not over four hogsheads high (fig. 14), and space was left between the rows for rentilation

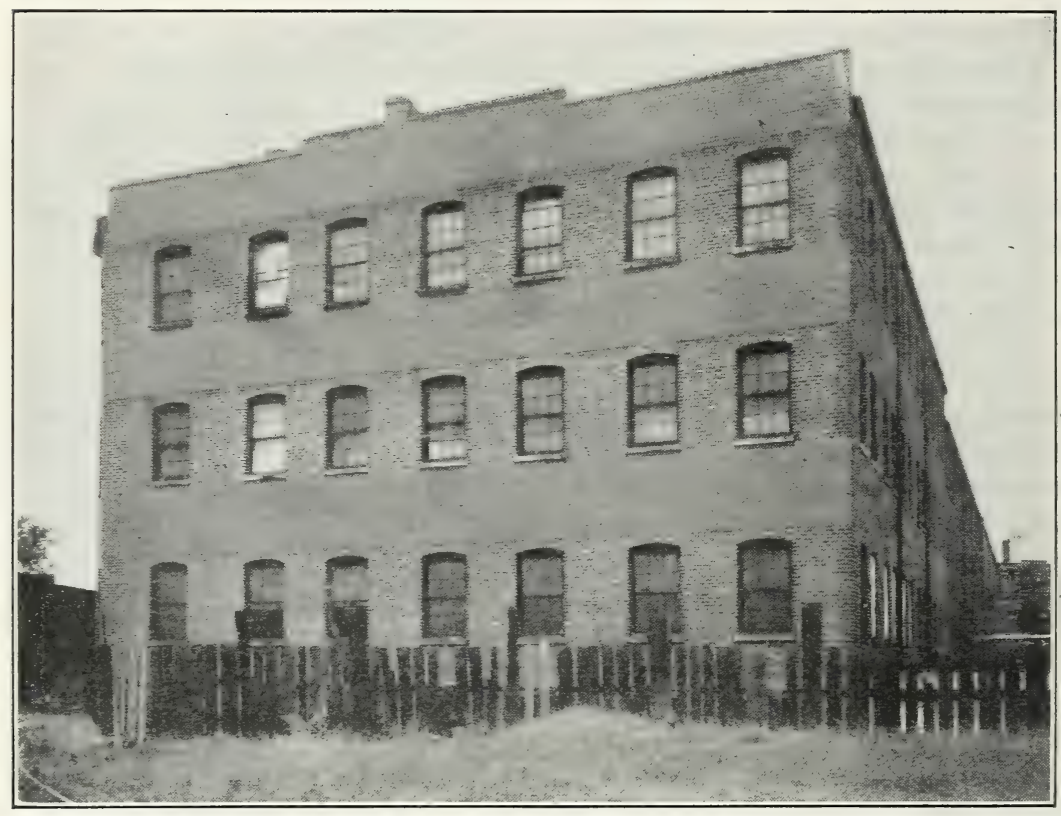

Figcre 12.-Closed tobacco-storage warehouse containing three stories and a basement. This warehouse was fumigated periodically during 1932 for the control of the tobacco moth.

and for the use of laborers in moving the hogsheads. The spray nozzles were so placed that the hydrocyanic acid would spray into the space between the rows of hogsheads.

The most satisfactoy method of sealing ventilators was found to be that of placing a piece of durable cardboard over the metal grate and then fastening a piece of gasproof tar paper to the brick wall, covering the entire ventilator. A thin strip of a good quality of heavy wrapping paper was then pasted over the edges of the tar paper to prevent them from warping from the heat of the sun. In figure 15 is shown a sealed rentilator which was torn open and photographed to illustrate the details of the sealing. 


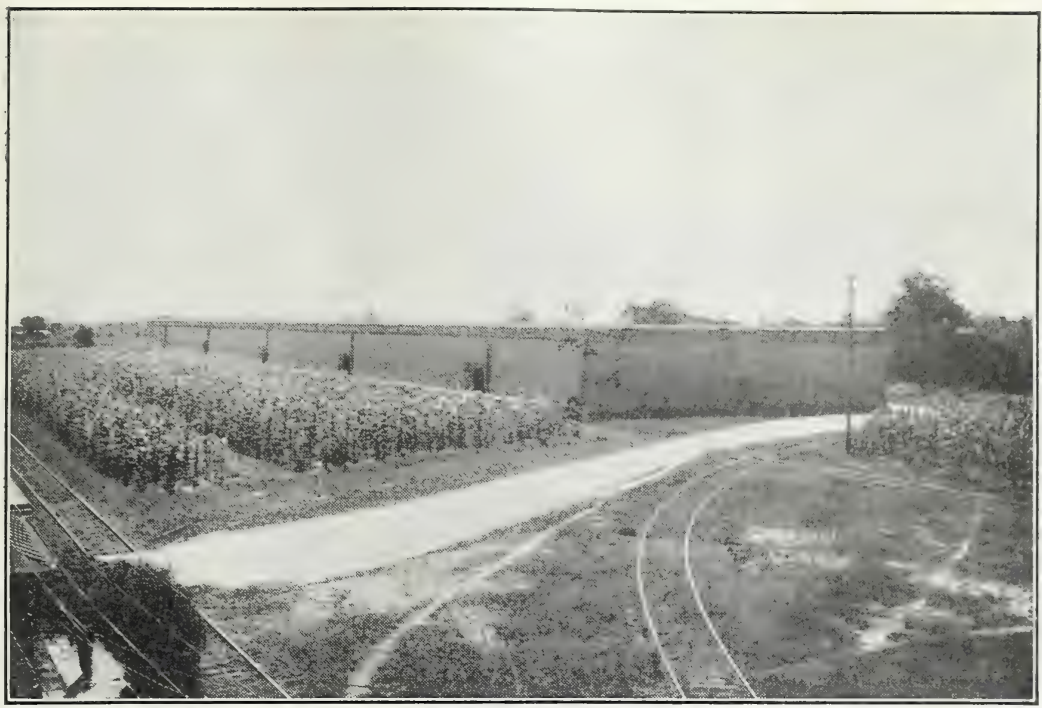

Figure 13.-Closed tobacco-storage warehouse one story high, divided into sections by fire walls. This warehouse was fumigated periodically during 1932 for the control of the tobacco moth.

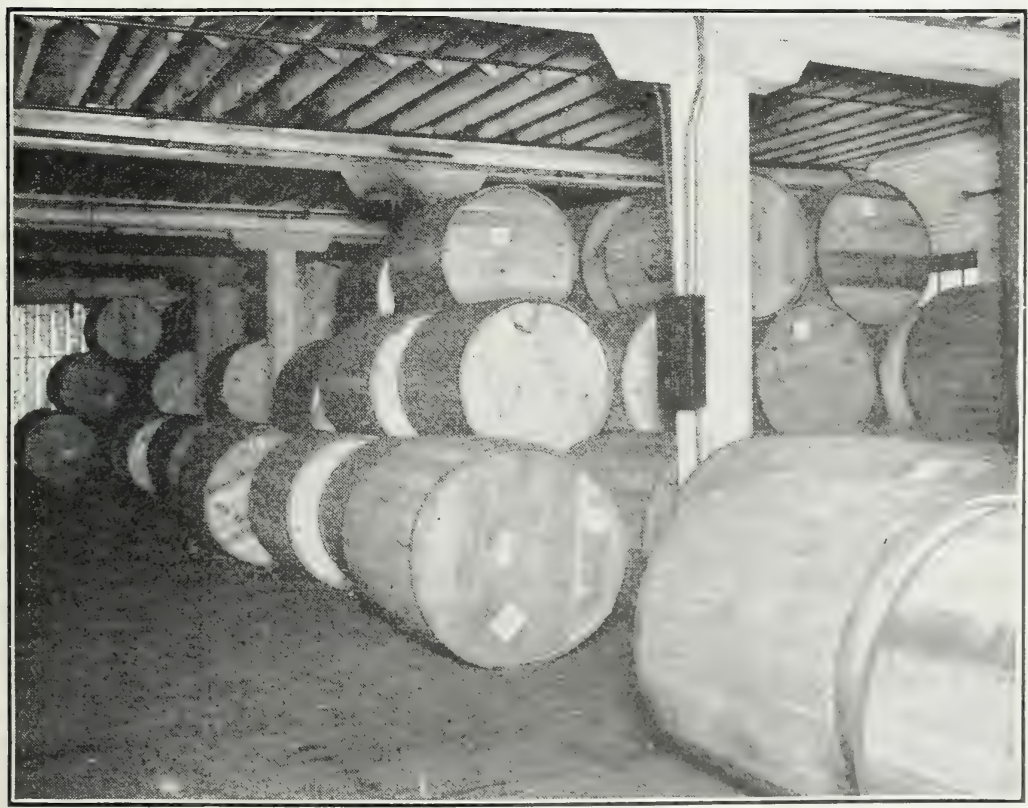

FIgure 14.-Hogsheads of flue-cured tobacco in storage. These hogsheads may remain here from 2 to 4 years during the aging period, and the tobacco moth may inflict severe damage unless the warehouse is fumigated periodically. 
The eares of the warehouses, wherever possible, were sealed from the inside with elastic roofing cement (fig. 16). This material was inexpensive, durable, and not difficult to apply. In some instances it was found necessary to seal the flashing around the eaves and the skylights from the roof. This sealing was satisfactorily done by pasting strips of a tough paper over the metal flashing where it

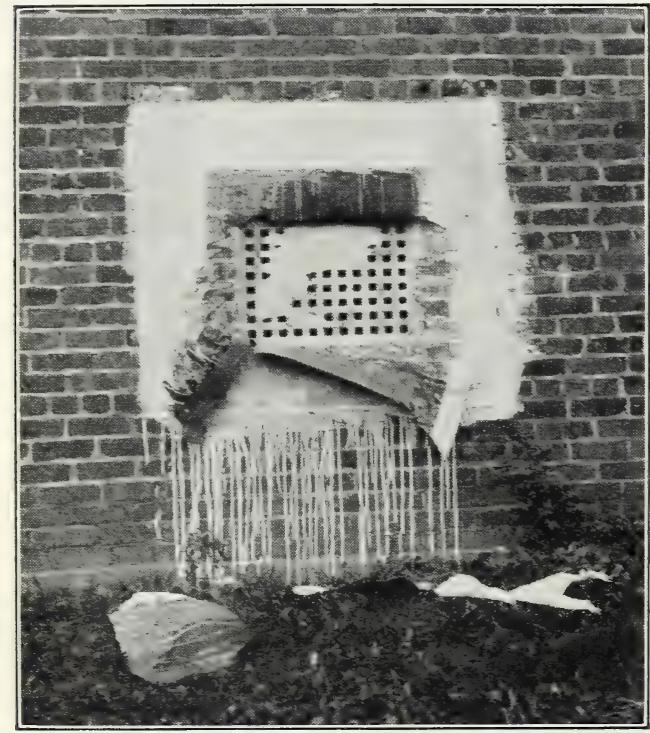

FIGURE 15.-A ventilator situated near the floor of a tobacco warehouse, showing the manner of sealing for fumigation. A portion of the cardboard is shown adhering to the ventilator, over which the tar paper had been sealed. joined the brick wall, by using a paperhangers' paste. This method of sealing from the roof is shown in detail in figure 17. It should be emphasized, however, that ordinarily a most effective seal was obtained from the inside, using the elastic cement, and it is recommended that, whenever possible, the eaves of tobacco warehouses be sealed from the inside.

Many of the windows in the warehouse shown in figure 12 had loose frames and were in poor condition, generally, and it was found advisable to seal the entire window space with a gasproof tar paper. The paper was cut to fit and tacked to the sills and facing. A wooden strip was then tacked over the paper along the window frames and elastic roofing cement used for sealing along the edges. This method of sealing windows is shown in figure 18.

The sliding doors of the warehouses presented a difficult problem in sealing. A sealing mixture was developed, consisting of 4 parts of asbestos to 1 part of calcium chloride and sufficient water to make a stiff dough. This mixture was prepared in a large shallow box mounted on a small truck and was plastered around all edges of the doors, effecting a complete seal. The calcium chloride preserved the moisture in the asbestos and prevented cracking before the end of the experiment. This mixture had the advantage of cheapness and ease of application, and was easily removed from the doors at the end of the fumigation. In figure 19 is shown a door of a tobacco warehouse sealed for fumigation.

When the sealing operations were completed, the warehouses were fumigated with hydrocyanic acid. The method of introducing the fumigant is shown in figure 20. The copper pipes passing through the brick walls of the warehouses can be seen, and in the foreground are $1 / 2$-horsepower motors and compressors used to provide the required pressure in the cylinders, each of which contained 75 pounds of the fumigant in liquid form. 


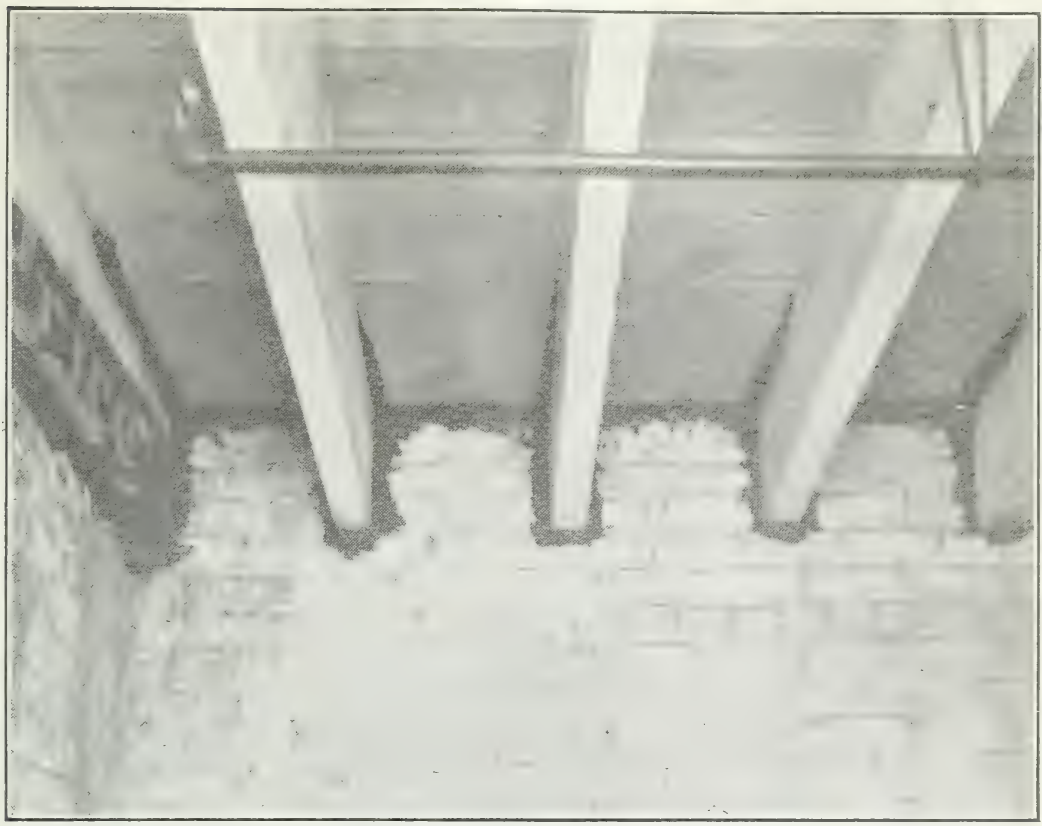

Figdre 16.-Eaves of a tobacco warehouse sealed with plastic cement from the inside of the building. This cement was forced with a pressure gun into any crevices througin which the fumigating gas might escape.

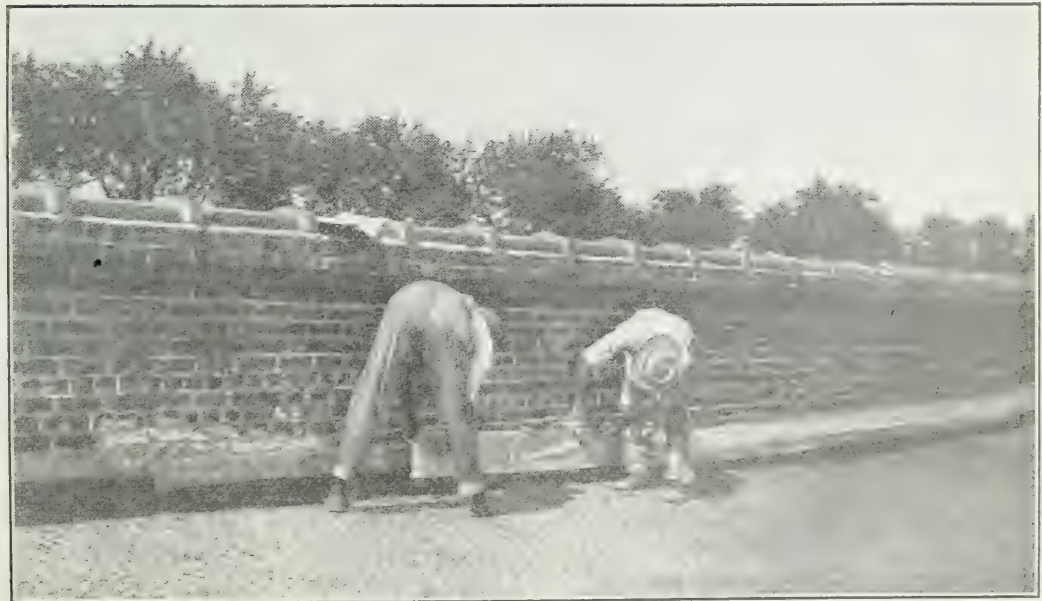

FigCre 17.-Eares of a tobacco warehouse sealed from the top of the building by pasting a strip of tough paper, 10 inches wide, over the flashing where it joins the brick wall. 


\section{CONTROL EXPERIMENTS OF 1932}

\section{PRELIMINARY TESTS}

Experiments in warehouses infested by the tobacco moth were carried out in 1930 and 1931 which showed that if this pest is to be held under control by atmospheric fumigation, a program of periodic fumigations must be devised. The experiments showed that it was rarely possible to obtain complete control of the tobacco moth from one fumigation at atmospheric pressure, regardless of the dosage of fumigant applied. A series of experiments was then outlined to fumigate 3,318,000 cubic feet of storage space (figs. 12 and 13) in which tobaccos were stored valued at approximately $\$ 10,000,000$. The infested warehouses were divided by brick fire walls into sections each containing about 200,000 cubic feet, and one spray nozzle was installed for each 30,000 cubic feet.

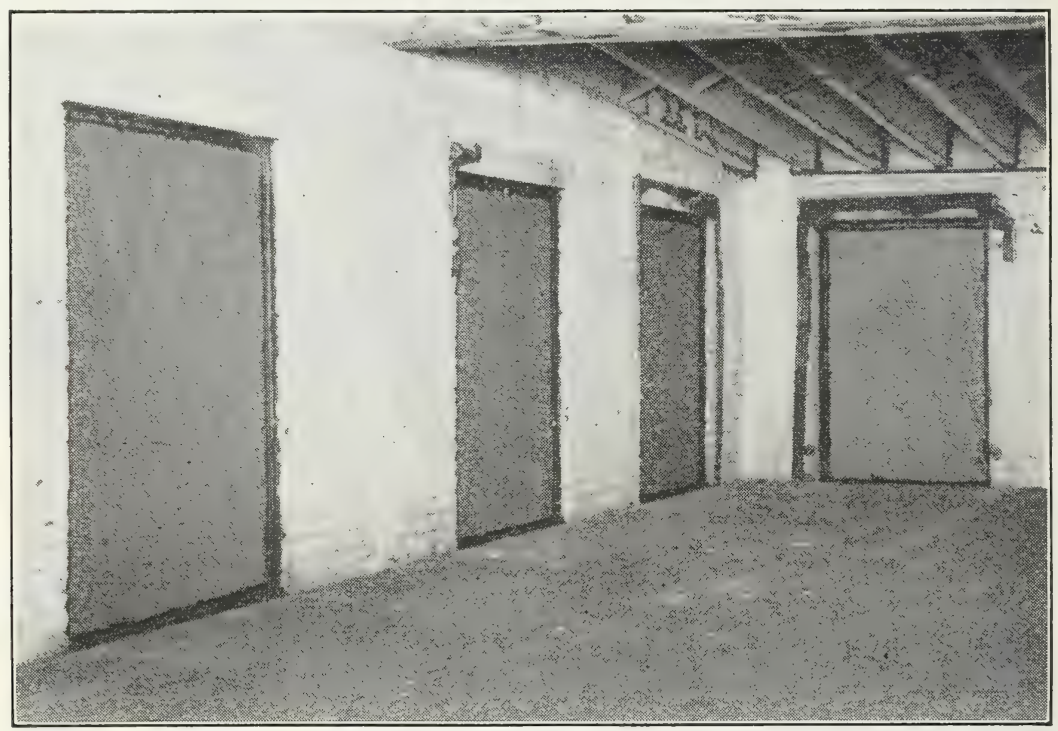

Figure 18. - A gasproof tar paper used for sealing the entire window space in a tobacco warehouse.

\section{LIGHT-TRAP INDICATORS}

On April 11, 1932, light traps, in which a sticky fly paper was used, were placed in the warehouses. Each of these traps consisted of a fabricated board 16 inches long, 10 inches wide, and three-eighths of an inch thick, on which a sheet' of sticky fly paper was fastened with thumbtacks. They were suspended at an angle of $45^{\circ}$ about 6 inches below electric lights (fig. 21). One such trap indicator was installed for about each 97,000 cubic feet of storage space. The tobacco moth was not positively phototropic to a high degree, but the catches of moths on these indicators served very satisfactorily as a guide in scheduling the periodic fumigations. 
The average weekly catch of moths for the period April 11 to October 31 and the average temperatures for each week are shown in table 7 . The first moths of the spring brool were collected from the trap indicators in the week which ended April 25. In the week which encled May 30 the average catch of moths per indicator was $2 \overline{\mathbf{r}} 0 . \overline{\mathbf{t}}$, and it was believed that this represented about the peak of emergence of the spring brool. 'The warehouses were sealed in the manner already

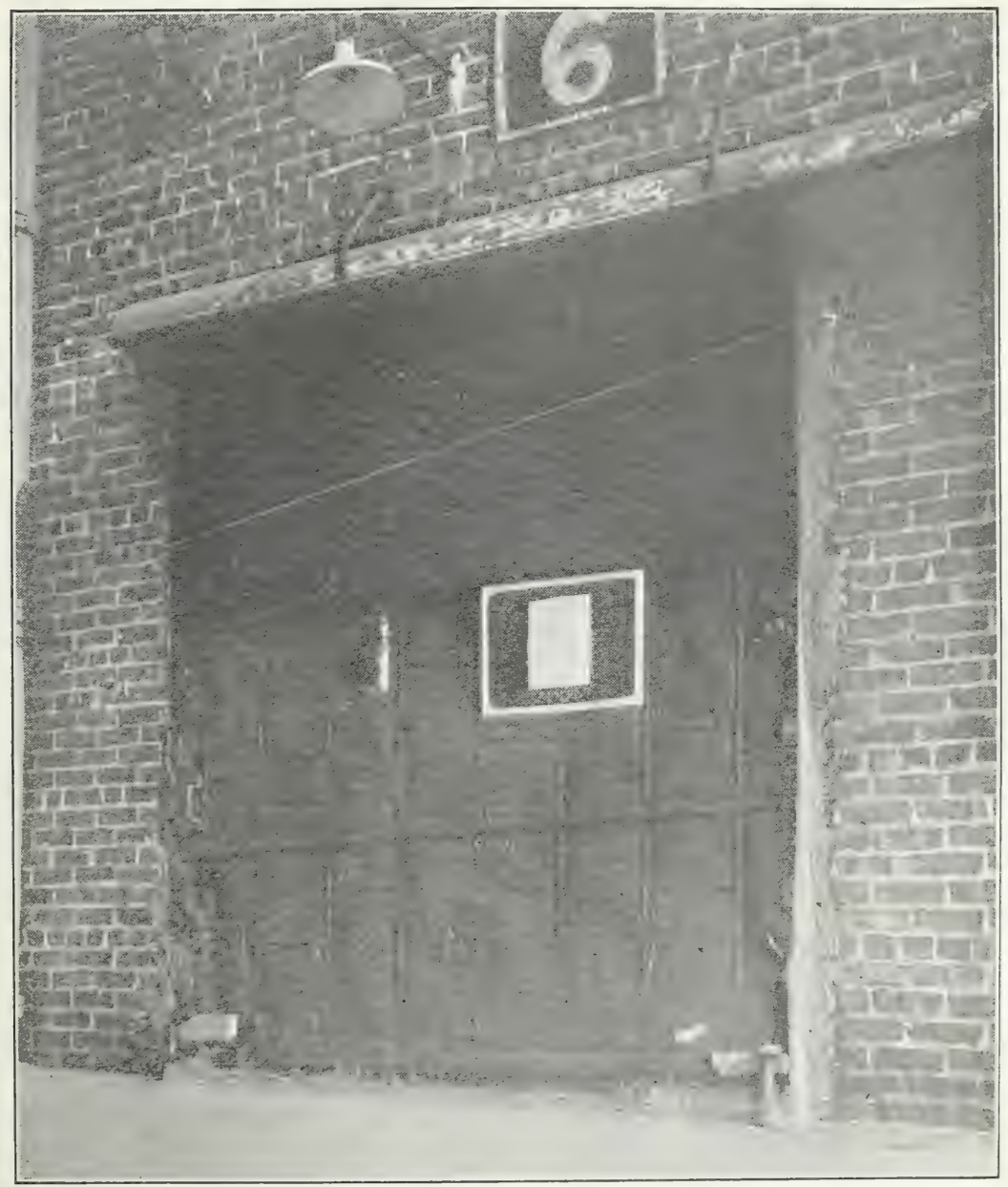

FIGURE 19.-Sliding door of a tobacco warehouse sealed with a mixture of asbestos and calcium chloride in preparation for fumigation.

described and were fumigated on June 1, using a dosage of 10 ounces of hydrocvanic acid per 1.000 cubic feet of storage space and an exposure of 72 hours. Fumigations at this dosage and exposure were repeated in the warehouses on June 28. Augu-t 3 , and September 8 . The total and the average catches of noths per trap for each week are shown in table 7 . 
TABLE 7.-Weekly catch of tobacco moths on 34 light-trap indicators placed in infested storages Apr. 4, and the dates of fumigation, Richmond, Va., 1932

BEFORE FUMIGATION

\begin{tabular}{|c|c|c|c|c|c|}
\hline \multirow[b]{2}{*}{ Week ended- } & \multicolumn{2}{|c|}{ Catch of moths } & \multicolumn{3}{|c|}{$\begin{array}{c}\text { A verage temperature in ware- } \\
\text { houses }\end{array}$} \\
\hline & Total & $\begin{array}{l}\text { Average } \\
\text { per in- } \\
\text { dicator }\end{array}$ & $\begin{array}{l}\text { Maxi- } \\
\text { mum }\end{array}$ & $\begin{array}{l}\text { Mini- } \\
\text { mum }\end{array}$ & Mean \\
\hline $\begin{array}{l}\text { Apr. } 11 \\
\text { Apr. } 18 \\
\text { Apr. } 25 \\
\text { May } 2 \\
\text { May } 9 \\
\text { May } 16 \\
\text { May } 23 \\
\text { May } 30\end{array}$ & $\begin{array}{r}\text { Number } \\
0 \\
0 \\
3 \\
14 \\
32 \\
256 \\
2,386 \\
9,203\end{array}$ & $\begin{array}{c}\text { Number } \\
0.09 \\
.4 \\
.9 \\
7.5 \\
70.2 \\
270.7\end{array}$ & $\begin{array}{r}\circ{ }^{\circ} \\
61 \\
61 \\
74 \\
71 \\
80 \\
71 \\
73 \\
81\end{array}$ & $\begin{array}{l}\circ F . \\
43 \\
37 \\
37 \\
51 \\
56 \\
53 \\
52 \\
56\end{array}$ & $\begin{array}{l}\circ F . \\
52 \\
49 \\
61 \\
61 \\
68 \\
68 \\
63 \\
68\end{array}$ \\
\hline
\end{tabular}

WAREHOUSES FUMIGATED JUNE 1 AND 2

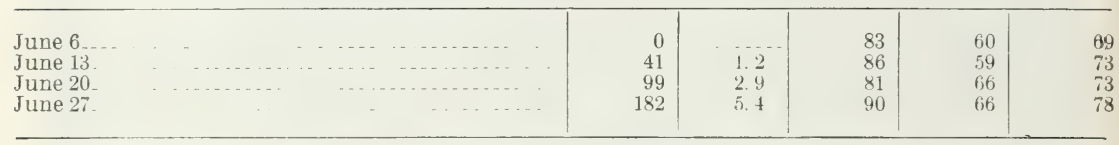

WAREHOUSES FUMIGATED JUNE 28

\begin{tabular}{|c|c|c|c|c|c|}
\hline 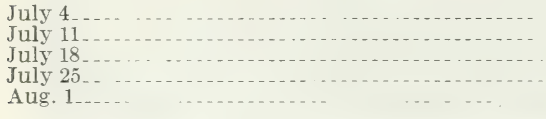 & $\begin{array}{r}0 \\
8 \\
126 \\
321 \\
766\end{array}$ & $\begin{array}{r}0.2 \\
3.7 \\
9.4 \\
22.5\end{array}$ & $\begin{array}{l}83 \\
90 \\
90 \\
93 \\
91\end{array}$ & $\begin{array}{l}64 \\
68 \\
70 \\
68 \\
68\end{array}$ & $\begin{array}{l}74 \\
79 \\
80 \\
80 \\
79\end{array}$ \\
\hline
\end{tabular}

WAREHOUSES FUMIGATED AUG. 3

\begin{tabular}{l|r|r|r|r|r}
\hline Aug. 8 & 0 & & 88 & 65 & 75 \\
Aug. 15 & 43 & 1.3 & 90 & 67 & 78 \\
Aug. 22 & 123 & 3.6 & 86 & 66 & 76 \\
Aug. 29 & 946 & 27.8 & 92 & 65 & 85 \\
Sept. 5 & 652 & 19.2 & 97 & 73 & 81 \\
\hline
\end{tabular}

WAREHOUSES FUMIGATED SEPT. 8

Sept. 12
Sept. 19
Sept. 26
Oct. 36
Oct. 10
Oct. 17
Oct. 24
Oct. 31

\begin{tabular}{r|r|r|r|r}
0 & & 91 & 70 & 81 \\
0 & & 98 & 68 & 74 \\
101 & 3.0 & 80 & 62 & 71 \\
166 & 4.9 & 76 & 52 & 64 \\
241 & 7.1 & 75 & 49 & 62 \\
248 & 7.3 & 69 & 48 & 58 \\
71 & 2.1 & 72 & 53 & 62 \\
24 & .7 & 66 & 47 & 56 \\
\hline
\end{tabular}

RESTITS OF PERIODIC FTMIGATIONS

In figure 22 are shown the average weekly catch of moths per trap. the dates of the periodic fumigations, and the average maximum and minimum temperatures each week for the period May 2 to October 31,1932 . As shown in table 7 , the average catch of moths per indicator for the week prior to the fumigations on June 1, June 28, August 3, and September 8, respectively, were as follows: 270.7, 5.4, 22.5, and 19.2. After the final fumigation on September 8, the indicators were operated until October 31 , and the highest average catch of 
moths was 7 for the weeks ended October 10 and 17. Although the tobacco moth is not positively phototropic to a high degree, it has been determined ${ }^{4}$ that light traps of the type described above were satisfactory for indicating the progress of emergence and the dates for periodic fumigations. Since it has been recommended that fumigations be carried out in warehouses when the average catch of moths reaches 30 per week, all of the fumigations after. Iune 1 were

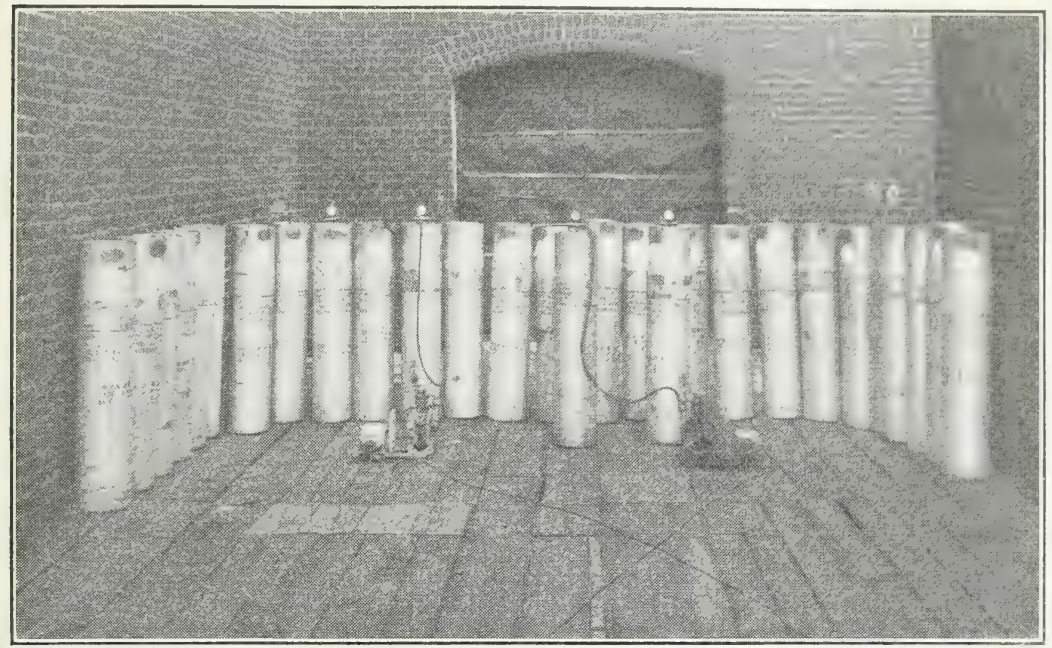

Figure 20.-Cylinders of hydrocyanic acid and air compressors used in connection with the fumigation of warehouses for control of the tobaceo moth in 1932. The copper pipes entering the warehouse through the brick wall can be seen on the rear wall at the right.

conducted when moth infestations were probably below the point of economic damage. It is believed, therefore, that the fumigation made on June 28 could have been delayed and that three fumigations during the season of 1932 would have sufficed to hold the tobacco moth under control.

\section{FACTORS INFLUENCING RESULTS IN WAREHOUSE FUMIGATIONS}

\section{DOSAGE, TEMPERATURE, AND PERIOD OF' EXPOSURE}

The dosage, temperature, and exposure were all found to be of importance in obtaining satisfactory results in controlling the tobacco moth by periodic fumigations at atmospheric pressure in closed tobacco warehouses. During experiments in 1930, 1931, and 1932, the writers used dosages of hydrocyanic acid ranging from $t$ to 24 ounces per 1,000 cubic feet of storage space. ${ }^{\mathrm{T}}$ It was concluded 4 Reed, W. D., Livingstone, E. M., and Morrill, A. W., JR. The Fumigation of To-
Bacco warehouses. U. S. Dept. Agr., Bur. Ent. and Plant Quarantine Cire. E-325, illus. 1934. [Mimeographed.] 


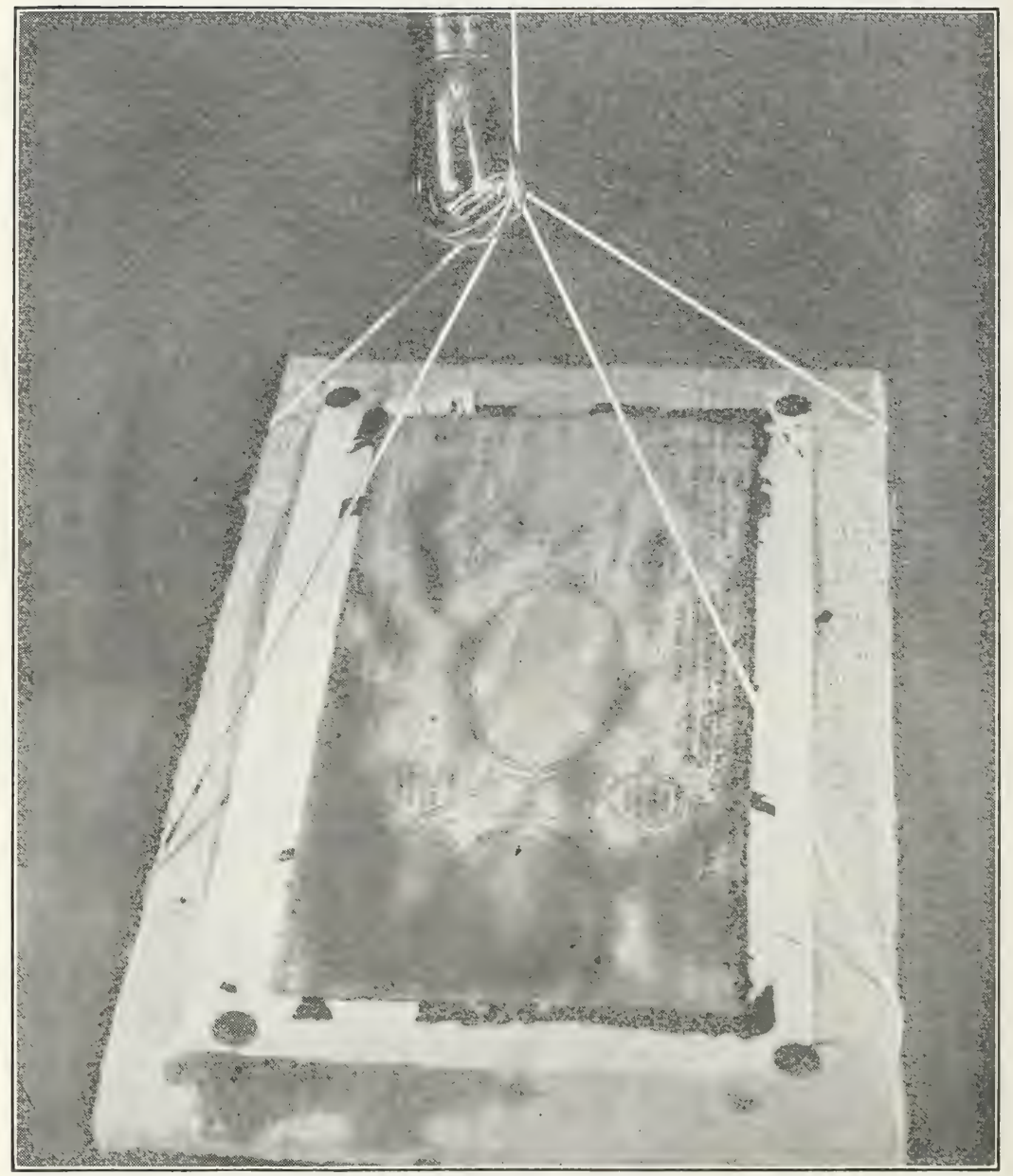

Figure 21. - Trap to denote the presence of tobacco moths in infested warehouses. When the average catch of moths per indicator per week reaches 30 , the warehouse should be fumigated. 
$\circ \quad\left(\exists_{0}\right) \exists y \cap \perp \forall y \exists d W \exists \perp$

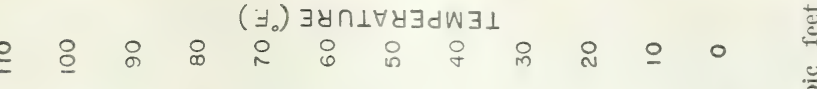
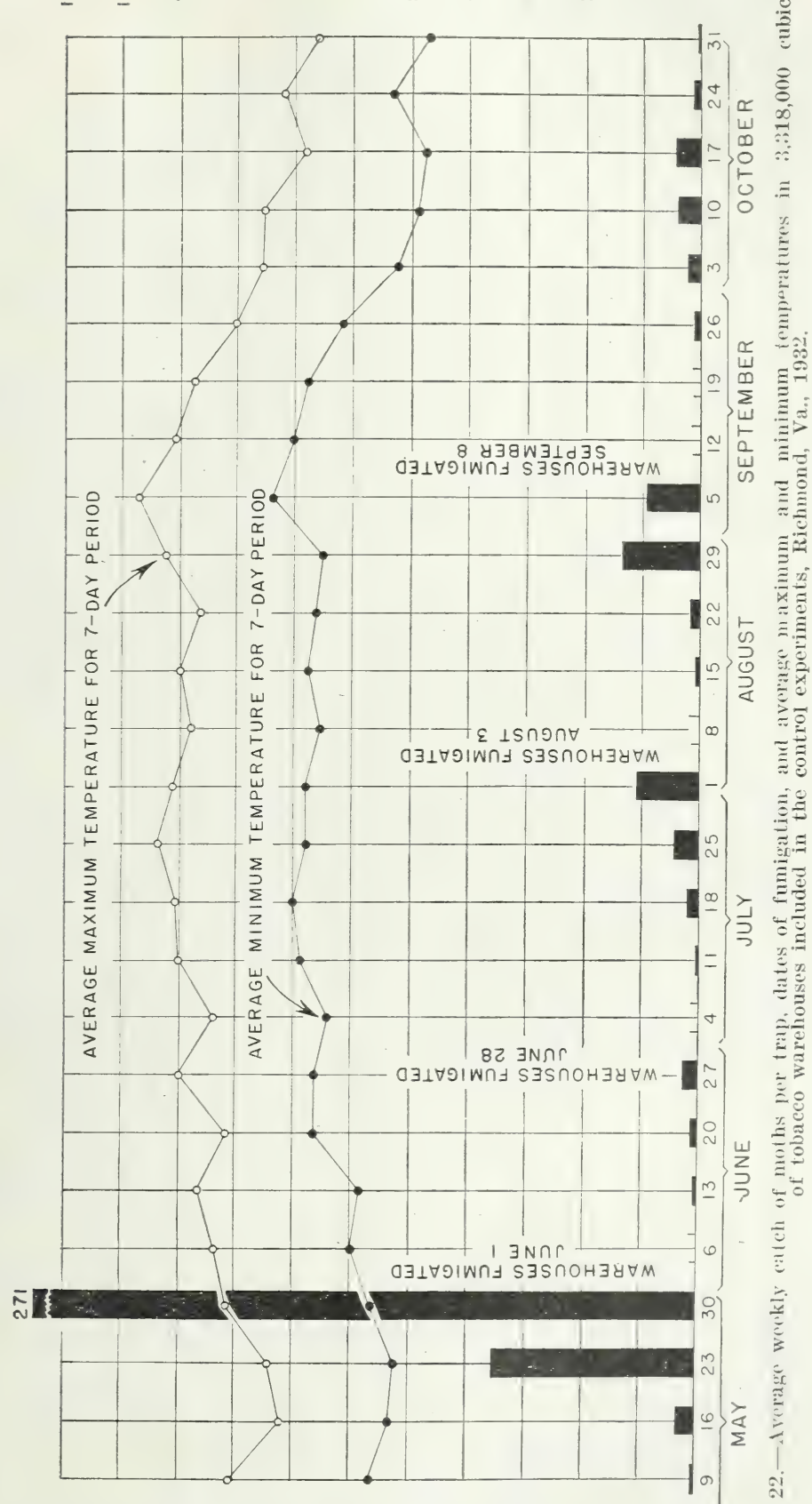

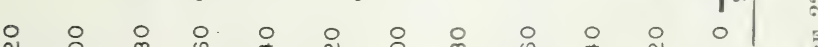

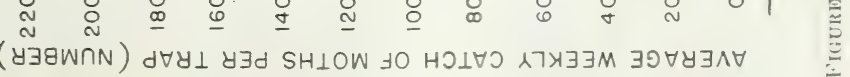


from the results of this work that dosages of hydrocyanic acid higher than 16 ounces were not economical to apply owing to the loss by leakage. In many instances it was found that a dosage of 10 ounces to 1,000 cubic feet was the most economical, when used for periodic fumigations during the warm months of the year. For best results in the fumigation of warehouses for control of the tobacco moth, it was found that the temperature of the stored tobacco should be $70^{\circ} \mathrm{F}$. or above. This requires that the control program in Virginia and North Carolina must ordinarily be limited to the period from June 1 to October 31.

Tine period of exposure which gave the most effective results in warehouse fumigation was 72 hours. It is recognized that some inrestigators, notably Page and Lubatti $(14,15)$, have found that, orring to factors of leakage and absorption, the concentration of hydrocyanic acid gas was greatly reduced after 6 or 8 hours. Neverthless, the results obtained in periodic fumigations of tobacco warehouses were more satisfactory with a 72 -hour exposure than when exposures of 24 and 48 hours trere used. The concentration of hydrocyanic acid gas in the air of tobacco warehouses under fumigation will vary with the different types of closed buildings, and this subject will also receive further investigation. The writers, unfortunately, were not equipped to determine the gas concentrations following the periodic fumigations mentioned in this circular. The control data given were obtained in experiments where only the factors of dosage, temperature of tobacco, and duration of exposure were considered.

CONSTRUCTION OF BUHDINGS

The type of construction in closed tobacco warehouses affected the results in fumigation. In warehouses having dirt floors corered with coal cinders. less satisfactory results were obtained from fumigations than in warehouses in which the floors were constructed of concrete or rood. The thickness of walls and the tightness of eares, rent:lators, skylights, windors, and doors all affect the results obtained from periodic fumigations. It was observed that in well-constructed warehouses two fumigations for the season were satisfactory, while in warehouses of poor construction three, and sometimes four, fumigations were necessary for satisfactory control.

MOVEMENT OF TOBACCO

Another important factor in the number of periodic fumigations required annually for controlling the tobacco moth is the normal morement of tobacco in storage. In warehouses, especially in large storage centers, there is a rather constant morement of aged tobaccos from the rarehouses throughout the year, either for export or domestic manufacture, and of new-crop tobaccos into the warehouses from redrying plants $(1 . p .46)$. In many instances fermented tobaccos which have been stored for 1 year or more in isolated localities are transferred to the large storage centers. A record was made of all hogsheads of cigarette-type tobaccos, which had been stored for 1 year or more in other localities, that were moved into the $3.318,000$ cubic feet of warehouse covered by the data shown in figure 22. The receipts of the hogsheads of tobacco were summarized for the perion May 1 to October 31, 1932, and these data are shown in table 8 . 
TABLF 8.-Summary of receipts of hogsheads of tobasen which har been strifed for 1 year or more in other localities, Richmond, Va., 193 ?

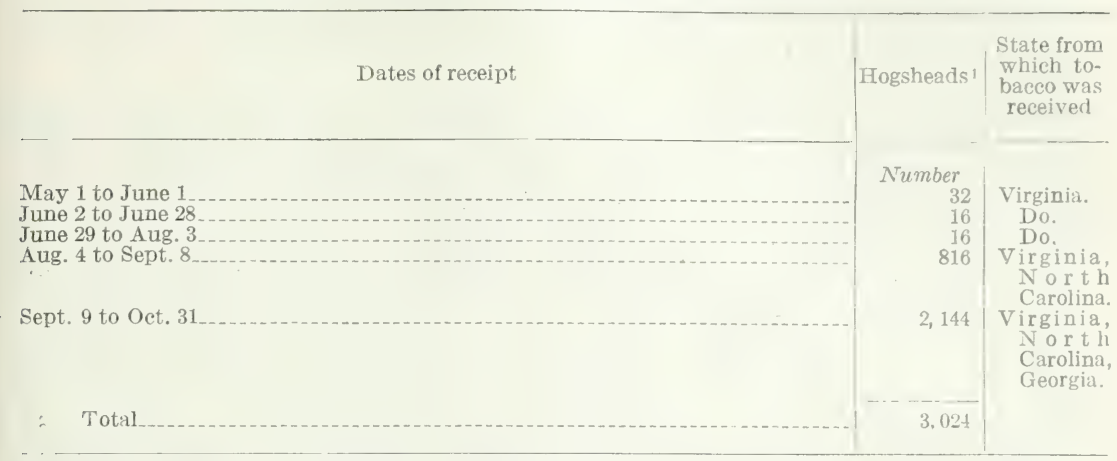

1 Average contents, 1,000 pounds net.

The 3,024 hogsheads (approximately 3,024,000 pounds) of old tobaccos were not segregated in the warehouses, but were distributed in the various sections according to grade of tobacco, in accordance with regular warehouse practice. These old hogsheads came from storage centers where there was known to be tobacco moth infestation. and observations showed that some of the hogsheads contained moth infestations when receired. It was not feasible to open and inspect. these hogsheads upon receipt, owing to the cost of such inspection and the interruption to warehouse procedure. Observations were occasionally made, however, on lots of hogsheads, which showed that some moth infestation was being brought into the warehouses in these old tobaccos. It was concluded, for example, that most of the infestation shown by the light-trap indicators from August 4 to September 8 came from the 816 old hogsheads received in the warehouses during: that time. Likewise, the 2,144 hogsheads received from September 9 to October 31 provided most of the infestation which appeared on the indicators during that period. This movement of old tobaccos into warehouses is an important factor in evaluating results from periodic fumigations of tobacco warehouses. It is often impractical to have all hogsheads fumigated immediately prior to their being placed in warehouses. This procedure would require specialized apparatus, such as vacuum or atmospheric chambers, and would often interrupt warehouse routine.

\section{COST OF THE CONTROL PROGRAM OF 1932}

Records were made of all expenditures for the fumigation experiments in the warehouses, the results of which are shown in table 7 and figure 22 , including hydrocyanic acid, materials for sealing the warehouses, labor, and the service charges of a commercial fumigator. The average cost per 1,000 cubic feet of space fumigated (total for four fumigations), using a dosage of 10 ounces of licuicl hychocranic acid. was 61.2 cents, and the average cost per hogshead of tobacero protected was 9.8 cents. These costs were distributed as follows: Hydrocyanic acid, 81.2 percent; materials for sealing. $t$ percent; labor, 6.3 percent; and services of a commercial fumigator. 8.5 per- 
cent. Since a hogshead of high-grade cigarette-type tobacco is valued at about $\$ 300$ (November 1936), this low cost presents no obstacle to owners of infested warehouses who would fumigate periodically for the control of the tobacco moth.

\section{RECOMMENDATIONS FOR TOBACCO MOTH CONTROL IN CLOSED WAREHOUSES}

Since it was demonstrated in the warehouse experiments summarized in figure 22 that effective penetration of hydrocyanic acid gas was rarely obtained deeper than 3 inches in hogsheads of tobacco, it is recommended that periodic fumigations be carried out in warehouses during the warm months of the year. In most instances grown larvae of the moth migrate to the surface of hogsheads of tobacco and seek a sheltered place in which to pupate and transform to the adult. From this time until the death of the moth, a period of approximately 3 weeks, the insects remain at or near the surface of the tobacco. The eggs, larvae, pupae, and adults that are near the surface of the tobacco are all vulnerable to the gas, and effective control may be obtained by atmospheric fumigation at the opportune time. Unsatisfactory results often occur when fumigation is performed during the period when most of the brood is in the larval stage, and feeding several inches below the surface. It is very important, therefore, to time the periodic fumigations to correspond with the emergence of the broods of adults from May to October.

The indicator shown in figure 21 may be used successfully to determine the dates for fumigation. One of these indicators should be placed in the warehouse for each 50,000 cubic feet of storage space. They should be suspended at an angle of $45^{\circ}$ approximately 6 inches beneath electric lights. The most efficient light for use in connection with the indicators was the 40 -watt bulb. It is recommended for the best results that only those lights over the indicators be allowed to burn during the night. The following control program is suggested for closed storage warehouses:

(1) Place indicators in tobacco warehouses prior to the emergence of the spring brood of tobaceo moths. (In Virginia and North Carolina this date is approximately May 15.)

(2) When the average catch of tobacco moths is 30 per indicator per week, fumigate the infested warehouses with hydrocyanic acid, using a dosage of 10 ounces of the liquid per 1,000 cubic feet, with an exposure of 72 hours.

\section{SAFEGUARDS IN FUMIGATION}

It would be impossible to overemphasize the importance of properly planning and carrying out the fumigation of tobacco warehouses $(1, p .50)$. The use of toxic gases, especialy hydrocyanic acid gas, is dangerous to human life unless fumigators are equipped with properly fitted gas masks and are skilled in the use of the fumigant. Data regarding suitable gas masks and other equipment required in fumigation can be obtained from the fumigant manufacturers. The local fire departments should be notified of the date of fumigation, and all other agencies concerned should cooperate fully in carrying out regulations designed to safeguard lives and property.

After a warehouse has been prepared for receiving the gas, a careful search should be made to determine that laborers or other persons have vacated. Conspicuous signs should be placed on the doors and 
guards provided to keep persons or domestic animals away. When the warehouse is opened for ventilation, a minimum of 12 hours should elapse before any one is permitted to enter. In moist weather this period should be extended. A trained fumigator should then inspect the warehouse and notify the personnel when it is safe to resume work.

If a person should be overcome by the gas used in fumigation he must be taken into the fresh air immediately and a physician called. In cases of poisoning with hydrocyanic acid gas fresh air should enter the lungs in a manner similar to normal respiration. If the person affected is breathing normally, it is often a satisfactory course to take him into the open air and make him breathe the fumes of ammonium carbonate, which will assist the victim in recovery. Fumigators should have a supply of this chemical at hand for use as an antidote for cyanide gas. If breathing has stopped or is irregular, artificial respiration should be employed at once. One of the most efficient means of promoting respiration artificially is the Schafer prone-pressure method. A summary of this method of resuscitation has been given in a recent circular of the United States Department of Agriculture $(1, p .52)$ and therefore will not be repeated here, but all persons engaging in fumigation work should request the fumigant manufacturers to supply the details of the process. All persons responsible for carrying out fumigations should be familiar with the best known antidotes for gas poisoning and the proper technique of artificial respiration.

\section{DISCUSSION}

The control recommendations given in this circular pertain to large storage warehouses where the great bulk of cigarette-type tobaccos are stored, often for long periods, in order to allow the tobaccos to ferment prior to manufacture. Under these conditions the only fumigant found satisfactory in tests was hydrocyanic acid gas. This gas was not explosive or inflammable at the concentration found to be effective, and its use was approved, under prescribed safeguards, by fire insurance companies. Carbon disulphide was found to be a satisfactory fumigant for tobacco at atmospheric pressure, but when fumigating sections of storage space containing from 150,000 to 200.000 cubic feet each, the quantity of this fumigant required was so great that a real fire hazard was involved. The majority of fire insurance companies object to the use of carbon disulphide where the risk is so great.

Since it is not feasible to move the vast stores of cigarette-type tobaccos through specialized apparatus, such as steel chambers. for fumigation in partial vacuum, or into rooms constructed especially for fumigation at atmospheric pressure, the writers attacked the problem of control in the warehouses. It proved feasible to work out a fumigation schedule according to which applications of gas can be made at times when the maximum population of moths are vulnerable. This principle of insect control has been applied for many years in economic entomology, and for nearly all insecticides, except. in the field of fumigation. It is rarely possible to obtain a complete elimination of insects by the fumigation of large quantities of stored products under the conditions usually found in factories and ware- 
houses. In the United States for the last 15 years there has been an erer-increasing concentration of tobaccos held for long periods in storage, and the only practical solution of the insect problem under these conditions is periodic controls applied in the warehouses.

Specialized fumigation apparatus is being adapted for use in tobacco factories, in treating both unmanufactured tobaccos and manufactured products. A number of fumigants have been tested for use in partial vacuum and at atmospheric pressure, the most satisfactory of which were mixtures of ethylene oxide, 1 part, and carbon dioxide, 9 parts; methyl formate, 15 percent, and carbon dioxide, 85 percent; and hydrocyanic acid.

The most promising type of specialized apparatus for tobacco fumigation consists of racuum chambers. These are steel tanks constructed of the proper size to accommodate the load to be fumigated. Considerable quantities of unmanufactured cigar tobaccos, Turkishtype tobaccos, and manufactured tobacco products are being fumigated in these tanks. The chambers are filled with tobacco, and then the air is remored by a pump until a reading of 29 inches or slightly abore is recorded on a mercury gage. The fumigant is then admitted, and satisfactory results are usually obtained, when the temperature of the tobacco is above $70^{\circ} \mathrm{F}$., with an exposure of $31 / 2$ to 4 hours. Additional research must be carried out in this field of fumigation before recommendations are available.

\section{SUMMARY}

This circular includes the most important observations and studies made of the tobacco moth (Ephestia elutella) at Richmond, Va., from 1931 to 1934.

A review of the literature on the history and distribution of the moth shows it to be a general feeder on dried vegetable products, but the writers assume that unknown factors in the biology have prerented the insect from assuming greater importance as a storedproduct pest.

The moth was first recorded as a pest of tobacco in Crimea in 1913 and has since appeared infesting cigarette types of tobaccos in Bulgaria, Greece, Turkey, Rhodesia, England, Poland, and the United States.

The injury to cured tobacco is inflicted by the larvae of the moth. Often the entire leaf is consumed with the exception of the larger veins-a type of feeding resembling that of many species of leafeating caterpillars. The webbing made by the nearly mature larvae often gives infested tobacco an unsightly appearance.

The larvae were observed to attack most severely those grades of tobacco that contained the highest percentages of sugar in the leaf, which include the higher priced commercial grades of the flue-cures type.

Life-history studies made during 1932 and 1933 show that under the usual conditions of temperature and moisture prevailing in Virginia and North Carolina tnree broods of moths appear during the period April 24 to October 31. Larvae of three generations are produced each year. A small percentage of the first generation, approximately 50 percent of the second, and all of the third overwinter as larvae to emerge the next year as the spring brood of moths. 
The temperature was considerably higher in 1933 than in 19:32, and this was reflected in the more rapid development of the larrae and pupae, but it did not appear to affect inaterially the arerage inculbation period of eggs or the average length of adult life. Spring-broorl emergence began on April 21 in 1932 and on April 14 in 1933. Some larvae which emerged as spring-brood moths in 1933 had required more than a year to complete development, the maximum being 380 days.

Records of oviposition and longevity of $10 \mathrm{z}$ pairs of moth show that the greatest number of eggs obtained from one female was 260. and the maximum longevity of adults was that of a female in 19:3:3 that lived 25 days.

The maximum and minimum periods consumed in developing through the egg, larval, and pupal stages are summarized and di:cussed. The uneven rate of growth of larvae caused an orerlaping of generations, and it was concluded that this great variation could not be satisfactorily explained on the basis of temperature and cunality of food. The higher temperatures prevailing in 1933 caused a more rapid growth of larvae, permitting 84 second-generation inclividuals to complete growth, whereas in 1932 only 5 completed growth.

The natural enemies of the tobacco moth are a small braconid parasite, Microbracon hebetor, which attacks well-grown larvae; a mite of the genus Laelaps, predacious on adults; and a spider, Theridion tepidaiiom, which destroys hundreds of adults. None of these natural enemies exert effective control of moth infestations in warehouses.

Periodic atmospheric fumigation of tobace warehouses of the closed type proved effective in 1932. A dosage of 10 ounces of hydrocyanic acid per 1,000 cubic feet of storage space was used. Four fumigations were carried out between June 1 and September 8 at an average total cost of 61.2 cents per 1,000 cubic feet fumigated and an average cost of 9.8 cents per hogshead of tobacco.

Recommendations are given for the periodic fumigation of tolsacco warehouses, and the results of experiments in sealing closed-trpe storages are presented.

The importance of using every known safeguard to protect life and property during fumigation is emphasized.

\section{LITERATURE CITED}

(1) Back, E. A., and Cotton, R. T.

1935. industrial fumigation against insects. U. S. Dept. Agr. Circ. 369,52 pp., illus.

(2) and REED, W. D.

1930. EPHESTIA ELUTELlA HÜBNER, A NEW PEST OF CURED TOBACCO IN THE UNITED STATES. Jour. Econ. Ent. 23: 1004-1006.

(3) Bovingdon, H. H. S.

1931. PESTS IN CURED TOBACCO. THE TOBACCO BEETLE, LASIODERMA SERRICORNE FAB. AND THE CACAO MOTH, EPHESTIA ELUTELla HB. TObacco, no. 608, pp. 56-59, illus. London.

(4)

1933. REPORT ON THE INFESTATION OF CURED TOBACCO IN LONDON BY THE CACAO мотн Ephestia elUtella Hв. Gt. Brit. Empire Marketing Bd. Bull. 67, 92 pp., illus.

(5) Chittenden, F. H.

1897. SOME LITTLE-KNOWN IXSECTS AFFECTING STORED VEGETABI.E PRODTCTS: A COLLECTION OF ARTICLES DETAILING CERTAIN ORIGINAL OBSERVATIONS MADE UPON INSECTS OF THIS ClASS. U. S. Dept. Agr., Div. Ent. Bull. (n. s.) 8, 45 pp., illus. 
(6) DE ONG, E. R.

1925. the CURRant moth on Peanuts. (Econ. note) Pan-Pacific Ent. $2: 46$.

(7) Gibson, A., and Twinn, C. R.

1929. HOUSEHOLD INSECTS AND THEIR CONTROL (WITH A CHAPTER ON ANIMaL PESts other than insects). Canada Dept. Agr. Bull. 112

(8) JACK. R. W. (n. s.), 84 pp., illus.

1932. EPHESTIA ELUTELLA, HB., AS AFFECTING THE SOUTHERN RHODESIAN TOBACCO EXPORT TRADE. Rhodesia Agr. Jour. 29: 32-36.

(9) MASKEW, F.

1912. a SERious WALNUt PeSt. (EPHestia elutelda hüBN.) Calif. Comn. Hort. Monthly Bull. 1: 366-371, illus.

(10) Mokrzecki, Z. [i. e. S. A.]

1930. HEUMOTTE (EPHESTIA ELUTELLA HB.), EIN GROSSER SCHÄDLING DES ROHTABAKS IN DEN SPEICHERN, IHRE BIOLOGIE UND BEKÄMPFUNGSmittel. Doswiadezalnictwo Rolnicze 6 (pt. 3) : 3-29, illus. [In Polish. German résumé, pp. 26-29.]

(11) Mokrzecki, S. A., and Bragina, A. T.

1915. REPORT OF THE ENTOMOLOGICAL LABORATORY OF THE EXPERIMENTAL STATION OF SALGIR FOR 1913-1914. 9 pp. Simferopol, Crimea. [In Russian. Abstract in Rev. Appl. Ent. (A) 3: 613.]

(12) Mossop, M. C

1932. pests OF StORED tobacco in southern rHodesia. Mill. Agr. and Lands Bull. 850, 23 pp., illus. Also in Rhodesia Agr. Jour. 29: $245-265$, illus.

(13) NoRrIS, M. J.

1934. CONTRIBUTIONS TOWARD THE STUDY OF INSECT FERTILITY.-III. ADULT NUTRITION, FECUNDITY, AND LONGEVITY IN THE GENUS EPHESTIA (LEPIDOPTERA. PHYCITIDAE.) Zool. Soc. London Proc. 1934 (pt. 2) : 333-360.

(14) Page, A. B. P., and Lubatti, O. F.

1933. THE APPLIOATION OF. FUMIGANTS TO SHIPS AND WAREHOUSES. II. DISTRIBUTION OF HYDROGEN CYANIDE IN EMPTY WAREHOUSES. Jour. Soc. Chem. Indus. Trans. 52: 316T-323T, illus.

(15) and LubatTI, O. F

1933. THE APPLICATION OF FUMIGANTS TO SHIPS AND WAREHOUSES. III. PENETRATION OF HYDROGEN CYANIDE INTO BAGS OF RAW CACAO STACKED IN PILES OF DIFFERENT S'ZZEIS. Jour. Soc. Chem. Indus. Trans. 52: 323T-326T, illus.

(16) REAUMUR, R. A. F. DE

1737. MEMOIRES POUR SERVIR A L'HISTOIRE DES INSECTES. V. 3, illus. Paris.

(17) REED. W. D.

1935. NOTES ON THE DISTRIBUTION OF CURED TOBACCO INSECTS IN THE NEAR East. Ent. Soc. Wash. Proc. 37 (2) : 42-48.

(18) Livingstone, E. M., and Morrill, A. W. JR.

1933. A PEST OF CURED TOBACCO, EPHESTIA ELUTEILA HÜBNER. U. S. Dept. Agr. Cire. 269, 16 pp., illus.

(19) MorrinL, A. W. JR., and Livingstone, E. M.

1935. TRAPPING EXPERIMENTS FOR THE CONTROL OF THE CIGARETTE BEETLE. U. S. Dept. Agr. Circ, 356, 14 pp., illus.

(20) Richards, O. W., and Thomson, W. S.

1932. A CONTRIBUTION TO THE STUDY OF THE GENERA EPHESTIA, GN. (INCLUDING STRYMAX, DYAR), AND PLODIA, GN. (LEPIDOPTERA, PHYCITIDAE), WiTh NOTES ON PARASITES OF THE LARVAE. Ent. Soc. London, Trans. $80: 169-250$, illus.

(21) TChORBADJIEF, P.

1930. L'ENTOMOLOGIE AGRICOLE' ET LES INSECTES NUSIBLES AUX PLANTES DE CULTURE EN BULGARIE. 4th Internat!. Cong. Ent. Ithaca. Trans., pp. $[746]-756$.

(22) Ustinov, A. A.

1932. REVIEW OF THE PESTS OF TOBACCO IN ABKHAZIA OBSERTED DURING 1931. Sukhum, Abkhazsk Tabachm Zonal'naia Stantsïa. 38 pp. [In Russian.] 


\section{ORGANIZATION OF THE UNITED STATES DEPARTMENT OF AGRICULTURE WHEN THIS PUBLICATION WAS LAST PRINTED}

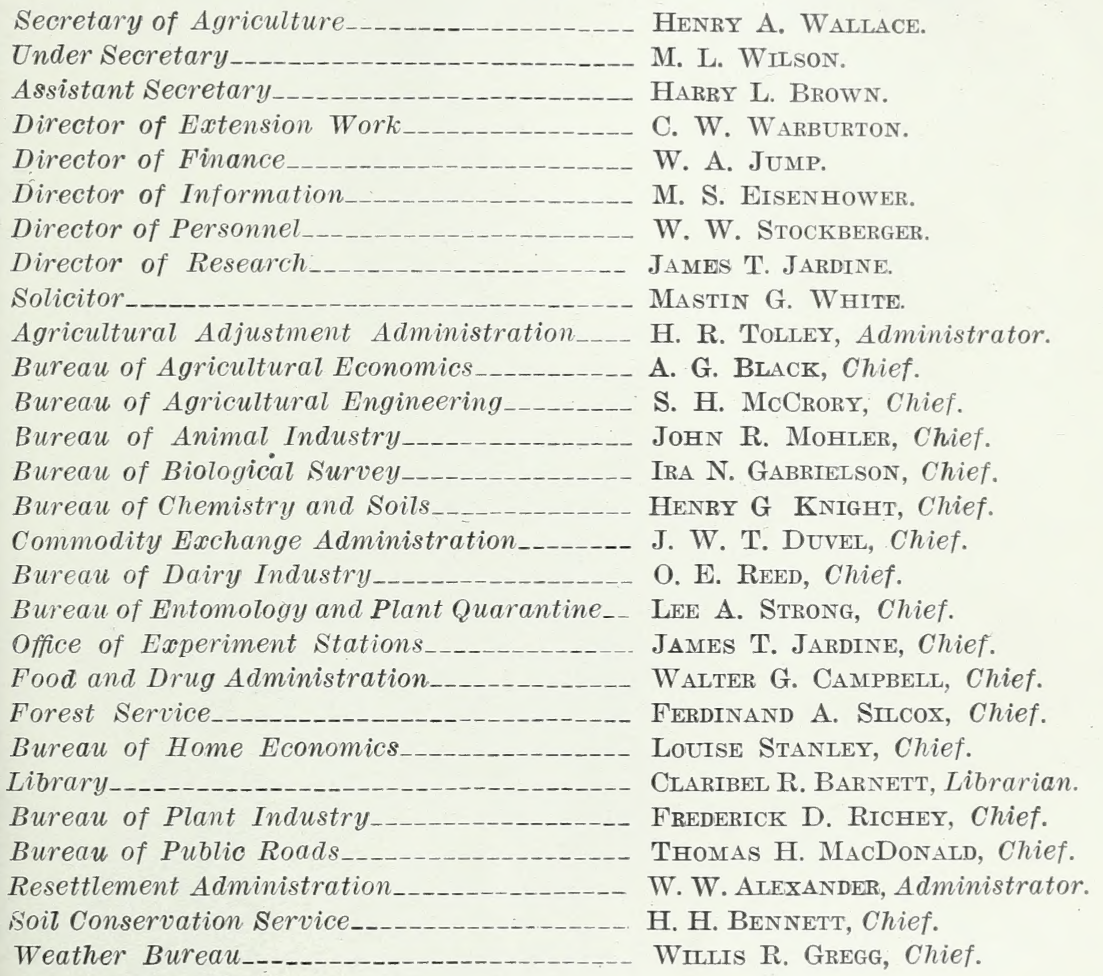

This circular is a contribution from

Bureau of Entomology and Plant Quarantine_ Lee A. Strong, Chief. Division of Truck Crop and Garden Insect W. H. White, Principal EntoInvestigations. mologist, in charge. 



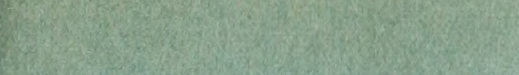


